\title{
It's elemental, my dear Watson: validating seasonal patterns in otolith chemical chronologies
}

Hüssy, Karin; Krüger-Johnsen, Maria; Thomsen, Tonny Bernt; Heredia, Benjamin Dominguez; Naeraa, Tomas; Limburg, Karin E.; Heimbrand, Yvette; McQueen, Kate; Haase, Stefanie; Krumme, Uwe Total number of authors: 13

Published in:

Canadian Journal of Fisheries and Aquatic Sciences

Link to article, DOI:

$10.1139 /$ cjfas-2020-0388

Publication date:

2021

Document Version

Peer reviewed version

Link back to DTU Orbit

Citation (APA):

Hüssy, K., Krüger-Johnsen, M., Thomsen, T. B., Heredia, B. D., Naeraa, T., Limburg, K. E., Heimbrand, Y., McQueen, K., Haase, S., Krumme, U., Casini, M., Mion, M., \& Radtke, K. (2021). It's elemental, my dear Watson: validating seasonal patterns in otolith chemical chronologies. Canadian Journal of Fisheries and Aquatic Sciences, 78(5), 551-566. https://doi.org/10.1139/cjfas-2020-0388

\section{General rights}

Copyright and moral rights for the publications made accessible in the public portal are retained by the authors and/or other copyright owners and it is a condition of accessing publications that users recognise and abide by the legal requirements associated with these rights.

- Users may download and print one copy of any publication from the public portal for the purpose of private study or research.

- You may not further distribute the material or use it for any profit-making activity or commercial gain

- You may freely distribute the URL identifying the publication in the public portal 
1 Title: It's elemental, my dear Watson: validating seasonal patterns in otolith chemical

2 chronologies

3

4 Authors

5 Karin Hüssy $^{1 *}$, Maria Krüger-Johnsen ${ }^{1}$, Tonny Bernt Thomsen², Benjamin Dominguez Heredia ${ }^{2}$,

6 Tomas Naeraa $^{3}$, Karin E. Limburg ${ }^{4,5}$, Yvette Heimbrand ${ }^{5}$, Kate McQueen ${ }^{6}$, Stefanie Haase ${ }^{6}$, Uwe

$7 \quad$ Krumme $^{6}$, Michele Casini ${ }^{5,7}$, Monica Mion ${ }^{5}$, Krzysztof Radtke ${ }^{8}$

8

9 Affiliations

$10{ }^{1}$ National Institute of Aquatic Resources, Technical University of Denmark, Kemitorvet, DK112800 Kgs. Lyngby, Denmark

$12{ }^{2}$ Geological Survey of Denmark and Greenland, Øster Voldgade 10, DK-1350 Copenhagen K., 13 Denmark

$14 \quad{ }^{3}$ Lund University, Department of Geology, Sølvegatan 12, SE-22362 Lund, Sweden

$15{ }^{4}$ State University of New York College of Environmental Science and Forestry, Syracuse, NY 16 13210, USA

175 Department of Aquatic Resources, Institute of Marine Research, Swedish University of 18 Agricultural Sciences, Turistgatan 5, SE-453 30 Lysekil, Sweden

$19{ }^{6}$ Thünen Institute of Baltic Sea Fisheries, Alter Hafen Süd 2, D-18069 Rostock, Germany

$20 \quad{ }^{7}$ Department of Biological, Geological and Environmental Sciences, University of Bologna, Via

21 Selmi 3, IT-40126 Bologna, Italy

$22{ }^{8}$ National Marine Fisheries Research Institute, Ul. Kołłątaja 1, 81-332 Gdynia, Poland

$23 *$ Corresponding author: kh@aqua.dtu.dk, Mobile +45 93511840 
25 Competing interests: The authors declare there are no competing interests.

26

27 


\section{Abstract}

29 Accurate age data is essential for reliable fish stock assessment. Yet many stocks suffer from 30 inconsistencies in age interpretation. A new approach to obtain age makes use of the chemical 31 composition of otoliths. This study validates the periodicity of recurrent patterns in ${ }^{25} \mathrm{Mg},{ }^{31} \mathrm{P},{ }^{34} \mathrm{~K}$, $32{ }^{55} \mathrm{Mn},{ }^{63} \mathrm{Cu},{ }^{64} \mathrm{Zn},{ }^{66} \mathrm{Zn},{ }^{85} \mathrm{Rb},{ }^{88} \mathrm{Sr},{ }^{138} \mathrm{Ba}$, and ${ }^{208} \mathrm{~Pb}$ in Baltic cod (Gadus morhua) otoliths from 33 tag-recapture and known-age samples. Otolith P concentrations showed the highest consistency in 34 seasonality over the years, with minima co-occurring with otolith winter zones in the known-age 35 otoliths and in late winter/early spring when water temperatures are coldest in tagged cod. The 36 timing of minima differs between stocks, occurring around February in western Baltic cod and one 37 month later in eastern Baltic cod; seasonal maxima are also stock-specific, occurring in August 38 and October, respectively. The amplitude in $\mathrm{P}$ is larger in faster-growing western compared to 39 eastern Baltic cod. Seasonal patterns with minima in winter/late spring were also evident in $\mathrm{Mg}$ 40 and $\mathrm{Mn}$, but less consistent over time and fish size than P. Chronological patterns in $\mathrm{P}$, and to a 41 lesser extent $\mathrm{Mg}$ and $\mathrm{Mn}$, may have the potential to supplement traditional age estimation or to 42 guide the visual identification of translucent and opaque otolith patterns used in traditional age 43 estimation.

$45 \quad$ Key words

46 Age validation, elements, microchemistry, otolith, physiology, seasonal patterns 


\section{Introduction}

48 Age information is one of the basic input variables in modern stock assessments, from which parameters such as growth, maturation patterns and productivity are estimated. Accurate age

50 estimates are thus crucial for reliable stock assessment and sustainable management of fish stocks.

51 Age has traditionally been determined by counting seasonally recurring growth zones in the fish's 52 otoliths (Campana, 2001). In temperate species, the timing of zone formation in otoliths is 53 generally linked with seasonal cycles, particularly in temperature, leading to clearly defined 54 growth zones and annuli (Beckman and Wilson, 1995; Høie and Folkvord, 2006; Weidman and 55 Millner, 2000). Due to the key role of age in stock assessment models, inconsistencies in the age estimates between readers can fundamentally influence the accuracy of the stock assessment.

57 Previously, to validate the accuracy of age estimates and/or the seasonality of growth zone 58 formation, a suite of methods has been used - see review in Campana (2001). Methods validating 59 the seasonality of zone formation indirectly include marginal increment analysis, date-specific 60 natural markers and length mode progression, while tag-recapture of chemically tagged fish is the 61 best-known direct method. In terms of validating absolute fish age, methods such as numerical 62 integration of daily increments, bomb radiocarbon and radiochemical dating are available 63 (Campana, 2001).

64 A new promising approach as a tool to validate zone formation, or even estimate absolute age, 65 makes use of the otolith chronological chemical composition. Interest in the chemical composition, 66 often termed "microchemistry", of otoliths has been increasing steadily over the last two decades 67 (see reviews in Campana (1999) and Sturrock et al. (2012)). The primary focus of these studies 68 has been the reconstruction of environmental exposure, notably the use of strontium (Sr), barium 69 (Ba) and manganese $(\mathrm{Mn})$ to infer migrations between areas with different salinities (Kraus and 
70 Secor, 2004; Sturrock et al., 2012) or hypoxia exposure (Altenritter and Walther, 2019; Limburg 71 et al., 2011; Mohan and Walther, 2016) and other elements as tracers of anthropogenic 72 contamination (Ranaldi and Gagnon, 2008). Elements that are under physiological control, such 73 as phosphorus (P) and zinc ( $\mathrm{Zn})$, on the other hand, have received far less attention (Campana, 74 1999). Seasonality in fish growth seems to be reflected in some of these elements. In a range of 75 species, otolith $\mathrm{Zn}$ correlates with visually-identified seasonal growth zones, with minimum $\mathrm{Zn}$ 76 concentrations occurring within translucent winter zones with visibly reduced daily growth rings 77 and check marks (Friedrich and Halden, 2010; Halden and Friedrich, 2008; Halden et al., 2000; 78 Limburg and Elfman, 2010). Higher otolith Sr levels have been observed instead to occur in opaque zones in Atlantic Bluefin tuna (Thunnus thynnus) (Siskey et al., 2016), with inverse patterns in sodium (Na) and potassium (K) (Seyama et al., 1991) - while Tomás et al. (2006) observed higher $\mathrm{Sr}$ and lower $\mathrm{Na}$ in translucent zones in European hake (Merluccius merluccius). Only recently has the use of seasonal patterns in the incorporation of elements under physiological control been suggested as an alternative method to derive fish age (Hüssy et al., 2016; Limburg et al., 2018). In a comparative age estimation approach on eastern Baltic cod (Gadus morhua), the first study of this kind, "visual" age readers with several decades' experience in traditional age interpretation achieved far lower precision than "microchemistry-based" age readers (Heimbrand et al., 2020), despite the fact that the latter had no formal manual to guide their interpretations. In this exercise, magnesium $(\mathrm{Mg})$, and phosphorus $(\mathrm{P})$ in particular, proved promising to be used as chemical clocks. However, to date no rigorous validation of such seasonality in element incorporation has been provided for any stock.

The present study aims at providing the first validation of the microchemistry-based age estimation approach, focusing on eastern Baltic cod. The eastern Baltic cod stock is a good case study, in that 
93 this stock is well known for its long-lasting issues with problematic traditional age readings

94 (Berner, 1968; Hüssy et al., 2016; ICES, 2015). The ageing issues eventually resulted in a 95 discontinuation of the traditional age-based stock assessment (Eero et al., 2015; ICES, 2014). Age

96 estimation in this stock is so difficult because the contrast between seasonal growth zones is very 97 small. This lack in contrast is primarily related to a combination of the hydrographic conditions 98 prevailing in the Baltic Sea proper, coupled with the movements of the cod through complex 99 thermal and salinity gradients (Baranova et al., 2011; Hüssy et al., 2010; Hüssy, 2010; Hüssy et 100 al., 2009; Hüssy et al., 2016). Additionally, suitable samples with known age derived from analysis 101 of daily increment analysis (DECODE, 2009; Hüssy et al., 2010; Hüssy et al., 2018) and a tag102 recapture program with chemically tagged otoliths from the "Tagging Baltic cod" project 103 (TABACOD, http://www.tabacod.dtu.dk/) are available (Hüssy et al. 2020a).

104 The trace element composition of otoliths depends on specific mechanisms of incorporation during 105 the biomineralisation process. Elements either substitute for calcium $(\mathrm{Ca})$ in the growing calcium 106 carbonate $\left(\mathrm{CaCO}_{3}\right)$ crystals, are randomly trapped in the interstitial spaces between crystals, or are 107 bound as co-factors in the organic matrix that provides the scaffolding for otolith crystal growth. $108 \mathrm{Sr}$ and $\mathrm{Ba}$ are known to substitute for $\mathrm{Ca}$, while $\mathrm{Mg}, \mathrm{K}$ and $\mathrm{Pb}$ are randomly trapped (Doubleday 109 et al., 2014; Izzo et al., 2016; Miller et al., 2006; Thomas et al., 2017). These elements therefore 110 reflect environmental concentrations. $\mathrm{P}, \mathrm{Cu}$ and $\mathrm{Zn}$ on the other hand are co-factors in enzymes 111 involved in biomineralisation of the otoliths, or active transport of carbonate across the 112 endolymphatic epithelium (Borelli et al., 2003; Payan et al., 2004), and are thus under strong 113 physiological control. Recent evidence suggests that Mn and Mg appear to occur in both crystal 114 and organic fraction of the otolith (Izzo et al., 2016; Thomas et al., 2017; Thomas and Swearer, 115 2019) and therefore presumably are under both environmental and physiological control (Hüssy et 
116 al., 2020b). Elements that substitute for $\mathrm{Ca}$ (elements of similar size and charge as $\mathrm{Ca}$ ), or are 117 randomly trapped in the $\mathrm{CaCO}_{3}$ crystal lattice, should therefore reflect ambient environmental 118 conditions in a consistent and predictable manner (Campana, 1999; Hüssy et al., 2020b), while 119 matrix-bound elements should be regulated by physiological processes (Limburg et al., 2018; 120 Hüssy et al., 2020b), reflecting seasonal variations in growth.

121 Based on the respective incorporation mechanisms of different elements, the objectives of this 122 study are to test the hypotheses that i) only elements under physiological control exhibit annually 123 recurring patterns in incorporation, linked to seasonal variations in environment and/or fish 124 physiology, ii) element incorporation is lowest during the coldest time of the year, iii) the number 125 of minima in element concentration corresponds to the fish's true age. Additional objectives of 126 this study are iv) to explore stock-related differences in element patterns, and v) to identify 127 elements that are most suited for age determination.

Materials and methods

131 The otoliths used in this study are from three different collections: one "test" collection and two 132 "validation" collections.

133 Test collection (TEST): This collection consists of 40 cod otoliths collected in the Kattegat (ICES 134 SD 21, see Fig. 1 for details on areas and sample locations) in December 2016. Otoliths from the 135 Kattegat are characterized by high contrast between seasonal translucent and opaque zones with 136 concurrent high age estimation precision and well established ageing protocols. These samples are 137 used as test group to identify the best approach for the analyses of element profiles. Details of cod 138 size and age are shown in Table 1. 
Validation collection 1 (DECODE): This collection consists of 53 otoliths from Baltic cod in the size range $150-350 \mathrm{~mm}$ captured in the Bornholm Basin (ICES SD 25) in February of 2001 and 2004 (Fig. 1, Table 1). In the otoliths of these cod, patterns in daily increments have previously been analysed in the DECODE project (DECODE, 2009). The DECODE project made use of a technique to estimate the age of young fish based on the width of daily otolith growth increments and has previously been used to identify problems with traditional age estimation (Hüssy, 2010) as well as to estimate changes in growth patterns (Hüssy et al., 2018). The width of daily growth increments is linked to the annual cycle in environmental temperature experienced by the cod (Hüssy et al., 2010). This results in distinct patterns where periods with clearly discernible increments formed during summer are interrupted by zones without regular increment structure during winter (DECODE, 2009; Hüssy et al., 2010). Counting these zones without increments thus provides an estimate of the fish's age, while their distance to the core provides a time stamp identifying the coldest time of the year the fish had experienced. These samples thus provide the means to validate both seasonality in element pattern formation as well as absolute age of the fish. Validation collection 2 (TABACOD): This collection consists of otoliths from the tag-recapture program "Tagging Baltic Cod" - TABACOD - carried out in the Baltic Sea. See Hüssy et al. (2020a) for details on tagging protocols, including release and recapture statistics. Tagged cod were $>250 \mathrm{~mm}$ at release and were marked externally using T-bar tags with a unique number identifying each fish throughout the years 2016 - 2019 (http://www.tabacod.dtu.dk/) (Fig. 1). Otoliths were marked with an injection of tetracycline-hydrochloride (TET), leaving a fluorescent mark in the otolith when viewed under UV light. Cod were tagged in the western (ICES SD 24) and eastern (ICES SDs 25 and 26) Baltic Sea. Stock identity of the recaptures was determined using a combination of genotyping and otolith shape based methods, the details of which are 
162 described in Hemmer-Hansen et al. (2019) and Schade et al. (2019). Days at liberty $(D A L)$ were 163 defined as the days between release of tagged cod and recapture. Since tagging was primarily 164 carried out in spring and fall (Hüssy et al., 2020a), the samples used in this study were restricted 165 to fish with $D A L>180$ in order to ensure temporal overlap of individuals across all seasons in all 166 years. A total of 143 recaptured cod (123 eastern and 20 western) in the length range $177-500$ $167 \mathrm{~mm}$ were available. For details on length and $D A L$ between tagging and recapture, see Table 1 and 168 Supplementary Fig. S1. These recaptures thus allow testing for annually recurring patterns in 169 element composition without the need to count daily increments. The tagging experiments were 170 171 172 $14823 / 2018$

Otolith preparation

175 For the TEST and the TABACOD samples, otoliths were soaked in deionized water, cleaned for 10 176 minutes in an ultrasonic bath of deionized water, rinsed under deionized water and left to dry 177 overnight under a laminar flow hood in acid-washed trays. Otoliths were embedded in Epoxy resin 178 (Struers $\left.{ }^{\circledR}\right)$ and sectioned through the core using an Accutom-100 multi-cut sectioning machine to 179 obtain a $10 \mathrm{~mm}$ wide block containing the rostral part of the otolith with the nucleus exposed at 180 the sectioned surface. The surface of each section was polished with $3 \mu \mathrm{m}$ abrasive paper mounted 181 on rotating disks (Buehler®) to obtain a smooth surface and cleaned in the ultrasonic bath again 182 as described above. Otolith sections were digitized using a Leica DCF290 camera at a 183 magnification of $380 \mu \mathrm{m} \mathrm{pixel}^{-1}$ with a standard setup ( $8 \mathrm{bit} / \mathrm{channel,} 2048 \times 1536$ pixel frame). 
184 For the TEST images, otolith translucent seasonal growth zones (TZ) were identified and counted.

185 The number of $T Z$ is assumed to correspond to the age of the fish (Fig. 2).

186 For the $D E C O D E$ samples, otolith preparation and imaging was similar to the above samples (for 187 detailed description see: Hüssy et al., 2010; Hüssy, 2010; Hüssy et al., 2018). For these otoliths, 188 measurements of the distance from the core to the middle of each successive winter growth zone 189 (WZ) along the dorsal growth axis were measured using ImageJ (Rueden et al., 2017), representing 190 a chronological age record of each fish (Fig. 3). Each individual element measurement (see below) 191 was assigned to the chronological age of formation in relation to the WZ. It is important to note 192 193 194 195 that all individuals were sampled in February. Since this is just prior to the coldest time of the year (occurring in March), daily increment analysis was not able to fully capture the last $W Z$, as this is just forming at the otolith edge. By definition, the "birthday" of fish is the $1^{\text {st }}$ January, and for fish caught after this date, the edge is also counted when ageing the fish. In the present case, the age of the fish therefore is the number of complete $W Z+1$.

The TABACOD otoliths were viewed under UV light using a Leica DMLB microscope (with a BP 355-425 excitation filter, magnification of $1.36 \mu \mathrm{m}$ pixel $^{-1}, 3,648 \times 2,736$ pixel frame) (Fig. 4).

The distance from the TET mark to the otolith edge was measured along the dorsal axis together with the total axis length from core to edge. Otolith growth $\left(G_{\text {oto }}\right)$ from TET mark to the otolith edge was linearly correlated with days at liberty $(D A L)$ (eastern: $G_{\text {oto }}=1.203 \cdot D A L, \mathrm{df}=255, \mathrm{r}^{2}$ $=0.74, \mathrm{p}<0.05$ : western: $\left.G_{\text {oto }}=1.880 \cdot D A L, \mathrm{df}=40, \mathrm{r}^{2}=0.82, \mathrm{p}<0.05\right)$. Otolith growth during the tagging period was thus approximately constant throughout the year. Each individual element measurement (see below) was assigned to a date of formation calculated from its distance to the TET mark and the proportional relationship between $D A L$ and $G_{\text {oto. }}$. 
207

Microchemistry

For the TEST and TABACOD samples, trace element analyses were carried out by Laser Ablation Inductively Coupled Plasma Mass Spectrometry (LA-ICP-MS) at the Geological Survey of Denmark and Greenland (GEUS), employing a NWR213 frequency-quintupled Nd:YAG solid state laser system from Elemental Scientific Lasers (ESI) that was coupled to an ELEMENT 2 double-focusing, single-collector magnetic sector field ICP-MS from Thermo-Fisher Scientific. Each transect line analysis used a beam diameter of $40 \mu \mathrm{m}$ and a laser fluence of $\sim 9.5 \mathrm{~J} / \mathrm{cm}^{2}$, a repetition rate of $10 \mathrm{~Hz}$, and a travelling speed of $5 \mu \mathrm{m} \mathrm{sec}-1$. This study focused on the measurement of magnesium $\left({ }^{25} \mathrm{Mg}\right)$, phosphorus $\left({ }^{31} \mathrm{P}\right)$, calcium $\left({ }^{43} \mathrm{Ca}\right)$, manganese $\left({ }^{55} \mathrm{Mn}\right)$, copper $\left({ }^{65} \mathrm{Cu}\right)$, zinc $\left({ }^{66} \mathrm{Zn}\right)$, strontium $\left({ }^{88} \mathrm{Sr}\right)$ and barium $\left({ }^{137} \mathrm{Ba}\right)$. For a complete overview of analytical settings, see Table S1a.

The DECODE collection was analysed at the Department of Geology at Lund University, employing a Teledyne Photon Machines G2 excimer laser coupled to a Bruker Aurora Elite quadrupole ICP-MS. The laser equipped with a HelEx 2-volume sample cell. Instrument tuning was done using the NIST612 glass standard, opting for high sensitivity and stable signal counts on relevant isotopes, and for a low oxide production (i.e. below $0.5 \%$ ). The analyses were set to run automatically using a standard-sample bracketing and with pre-ablation prior to each transect analyses. The background level was measured for 30 seconds before each measurement. Transect line analysis used a scan speed of $12 \mu \mathrm{m} \mathrm{sec}^{-1}$, circular spots, and laser repetition rate of $7 \mathrm{~Hz}$ and a fluence of $2 \mathrm{~J} \mathrm{~cm}^{-2}$ on the carbonate phases and $3 \mathrm{~J} \mathrm{~cm}^{-2}$ on the NIST glass. The following isotopes were measured: ${ }^{25} \mathrm{Mg},{ }^{31} \mathrm{P},{ }^{43} \mathrm{Ca},{ }^{55} \mathrm{Mn},{ }^{63} \mathrm{Cu},{ }^{64} \mathrm{Zn},{ }^{66} \mathrm{Zn},{ }^{85} \mathrm{Rb},{ }^{88} \mathrm{Sr},{ }^{138} \mathrm{Ba},{ }^{208} \mathrm{~Pb}$. For a complete overview of analytical settings, see Table S1b. 
229 Concentrations in all collections are reported as element:Ca ratios in ppm, using ${ }^{43} \mathrm{Ca}$ as an internal 230 standard element and calibrated to a Ca concentration of $38.3 \mathrm{wt}$ \% $\%$ to account for any parameters 231 affecting the ablation yield, such as plasma fluctuations and variation in the amount of ablated 232 material. Further details on operating conditions, data acquisition parameters, analytical protocols 233 and data processing techniques are described in Supplementary Table S1a and S1b and Serre et al. 234 (2018). In the following, element will be called by their abbreviations without their mass number. 235 The otoliths were analysed along a transect from the nucleus to the dorsal edge of the otolith 236 following the axis of maximum growth. The data thus represent elemental signatures spanning 237 from hatch to death of each individual. Values $>4 \mathrm{x}$ standard deviations from the transect mean 238 were treated as outliers and discarded. For $\mathrm{Mg}, \mathrm{Mn}, \mathrm{P}, \mathrm{Sr}$ and $\mathrm{Ba}$ less than 1\% outliers were 239 removed, for $\mathrm{Cu}$ and $\mathrm{Zn} 10-20 \%$ were considered outliers. Signal to noise ratios $\left(\mu^{2} / \mathrm{s}^{2}\right)$, where $\mu$ 240 and $\mathrm{s}$ are the mean and variance of measurements respectively were $<5$ in $\mathrm{Cu}$ and $\mathrm{Zn}$ in most 241 individual owing to the fact that their concentration is close to the analytical resolution threshold 242 (Serre et al., 2018). The results of these elements are shown with the others, but results are to be 243 treated with caution.

245 Statistical analyses

246 Peak detection: A standardised method for identifying extrema (minima and maxima) in the 247 elemental profiles was developed by first smoothing the profiles with local polynomial regression 248 "loess" in "R" (R Development Core Team, 2020). Local extrema, maxima Max and minima Min 249 were then identified with the "peaks" function, where a peak/valley is defined as the measurement 250 in a sequence which is greater/smaller than all other measurements within a window of width span 251 centred at that measurement (Constantine, 2007). Successful extremum identification depends on 
252 the correct settings of the algorithm. The optimal settings of the TEST sample were identified using 253 the profiles of $\mathrm{P}$ and $\mathrm{Mg}$, the most promising elements for age estimation (Heimbrand et al., 2020). 254 Combinations of settings were tested until the approach identified the maximum correspondence 255 in number of Min as the corresponding number of $T Z$ (Fig. 2). The distribution of the resulting 256 differences in $T Z$ - Min, of the P profiles show a consistent difference of one (Supplementary Fig. 257 S2), because the last Min in most samples was too close to the edge to be captured by any algorithm 258 settings (see Supplementary Fig. S3 for explanation). Laser scan speed and subsequent data 259 treatment differed between the two LA-ICP-MS facilities, designed to optimize data precision of 260 the respective instruments. The impact of these settings (TEST and TABACOD samples: $5 \mu \mathrm{m} \mathrm{s}^{-1}$, 261 averaging 4 consecutive measurements; $D E C O D E$ samples: $12 \mu \mathrm{m} \mathrm{s}^{-1}$, all measurements are 262 reported) was assessed, but no impact on extrema detection was found (see Supplementary Fig. S4 263 for explanation). The optimal settings identified were: "loess" with span (degree of smoothing) = 2640.3 and degree of polynomials $=2$, and "peaks" with span (minimum distance for peaks have to 265 be counted) $=151$ and without threshold value.

266 Validation $1(D E C O D E)$ : In the DECODE otoliths, element concentrations were analysed as a 267 function of distance to the core using the smoothing algorithm and minimum detection routine 268 defined from the TEST sample. Along the profile of all elements, the distance of each minimum 269 (Min) to the core was recorded, as well as the loess estimate at each Min. The extent to which the 270 distances from core to Min of an element co-occurred with $W Z$ from daily increment patterns was 271 assessed using a Linear Mixed Effects Model (LME) with Min as response variable, WZ as fixed 272 effect and minima within individual fish as random effects.

273 Validation 2 (TABACOD): Ideally, data of recaptures with $D A L>360$ and from different years 274 should be used for validating seasonality with tag-recapture data. Only few fish fulfil that 
275 requirement (Fig. S1). To mitigate for this shortcoming, data from all fish were pooled and treated 276 as a single-fish analysis. If there are identifiable patterns in such an approach, these are the result 277 of true seasonal variation in element incorporation across individuals and years. Without a 278 consistent seasonal element incorporation, the result would consist exclusively of noise. Element 279 concentrations typically show high inter-individual variation. In order to remove this variation, 280 relative element concentrations were calculated by dividing each measurement with the mean 281 value of all measurements from TET mark to otolith edge. Relative element concentrations were 282 then analysed as a function of date of formation using all measurement of all otoliths in the sample, 283 284 regardless of how many days at liberty they had. This dataset was then smoothed and Min as well as Max identified with the loess smoothing algorithm and peak detection routine defined from the 285 TEST sample. These analyses were carried out on individuals from the eastern and western stocks 286 separately.

\section{Results}

289 Validation 1: DECODE samples

290 For cod $<350 \mathrm{~mm}$, the correspondence between daily increment patterns and Min in element 291 signals was analysed. An example of profiles of each analysed element in relation to distance from 292 the core is shown for a 4-year old cod in Fig. 5. The analysis of correspondence between daily 293 increment patterns and element signals, shows that the distance of elemental Min is linearly related 294 with the corresponding winter zones $W Z$ (Fig. 6). Statistics of each correlation are summarized in 295 Table 2. An intercept of 0 and slope of 1 would be expected if Min and WZ corresponded directly. 296 A Min formation before $W Z$ would result in a negative intercept, formation after $W Z$ in a positive 297 intercept, while the intercept would not be statistically significant if the two co-occurred. However, 
298 both these values are not contained within the confidence intervals of any of the elements (Table 299 2), where all intercepts are significantly larger than 0 and all slopes differ significantly from 1 300 (LME, all $\mathrm{p}<0.05$ ). This suggests that minima in element patterns occur after the middle of the 301 winter zone identified from daily increment widths. Lowest correlation coefficients occur for the 302 environmentally regulated elements $\mathrm{Sr}$ and $\mathrm{Ba}$ (both $\mathrm{r}^{2} \leq 0.60$ ), while the elements under 303 physiological control - notably $\mathrm{P}$ and $\mathrm{Zn}$ - show the highest correlation coefficients (both $\geq 0.74$ ). 304 Also $\mathrm{Zn}, \mathrm{Pb}$ and the two elements under environmental and physiological control, $\mathrm{Mg}$ and $\mathrm{Mn}$, 305 have correlation coefficients of $\mathrm{r}^{2} \geq 0.62$. By far the strongest correlation between Min and $W Z$ is 306 found in $\mathrm{P}\left(\mathrm{r}^{2}=0.80\right)$. These results show that in $\operatorname{cod}<350 \mathrm{~mm}$, in particular $\mathrm{P}$ provides accurate 307 age estimates, followed by $\mathrm{Mg}$ and $\mathrm{Zn}$.

308 In order to explore the variability in these regressions further, histograms of known age derived 309 from daily increment patterns minus the number of element minima (WZ - Min) were examined 310 (Fig. 7). These histograms show that the highest proportion of correct age estimates were obtained 311

317 element profiles and the locations of $W Z$ and Min found that these discrepancies were largely 318 attributable to the smoothing and extremum detection functions used, more specifically their lack 319 of ability to identify Min close to the end of the profile at the otolith edge. Including this additional 320 by the physiologically regulated elements $\mathrm{Cu}(51 \%), \mathrm{P}(49 \%)$ and $\mathrm{Mg}$ ( 43\%) Zn (47\%) - and the environmentally regulated $\mathrm{Sr}(55 \%)$.The combined results of the two analyses (Table 2, Fig. 7) thus show that Sr provides the estimate with the highest accuracy (55\%), but with a much lower precision $\left(\mathrm{r}^{2}=0.57\right)$ compared to $\mathrm{P}\left(\right.$ accuracy $\left.49 \%, \mathrm{r}^{2}=0.81\right)$ and $\mathrm{Mg}\left(\right.$ accuracy $\left.43 \%, \mathrm{r}^{2}=0.73\right)$. For $\mathrm{P}$, the chemical method underestimates age by 1 year in a considerable proportion of individuals (31\%), while a smaller proportion of ages are overestimated. Visual inspection of Min at the otolith edge manually in the total Min number, resulted in considerably higher 
321 accuracies: $\mathrm{P}-80 \%, \mathrm{Mg}-81 \%, \mathrm{Sr}-77 \%$. Underestimation was thus primarily associated with 322 insufficient minima detection close to the otolith edge, while overestimation occurred in profiles 323 with evident sub-seasonal profile patterns (Fig. S3).

Validation 2: TABACOD samples

326 For tagged cod $>250 \mathrm{~mm}$ minima and maxima in element signals were identified in order to 327 identify generic patterns in extrema formation. In Fig. 8 the individual with the longest time at 328 liberty $(D A L=927$ days $)$ is shown as an example. The element profiles from TET mark to the otolith edge of this individual are typical for eastern Baltic TABACOD cod. Combining all profiles of fish with $D A L>180$ days, the relative element concentrations in relation to date of formation show conspicuous differences between elements and stocks, which mirrors those of Fig. 8. Elements under environmental control (Fig. 9) show moderate ( $\mathrm{Sr}$ ) to low (Ba, K) seasonal patterns with minima in summer and maxima in winter in eastern Baltic cod, while variations in the concentration of these elements seem random in western Baltic cod. In the elements under both environmental and physiological control (Fig. 10), $\mathrm{Mn}$ and $\mathrm{Mg}$, on the other hand show clear and highly consistent seasonal patterns in incorporation in both stocks.

In the elements under physiological control ( $\mathrm{Cu}, \mathrm{P}, \mathrm{Zn}$, ) (Fig. 11), phosphorus in particular exhibits strong seasonal patterns where Min and Max occur consistently at approximately 12-month intervals across all years in both stocks, but with stock-specific timing in extremum formation. In eastern Baltic cod, minima are formed in March and maxima around October, while for western Baltic cod, minima are formed around February and maxima in September/October. These patterns are mirrored in $\mathrm{Mn}$ (with the exception of an additional minimum in WBC), and Mg. Notably, the 
343 amplitude between Min and subsequent Max is larger in western than eastern Baltic cod, resulting 344 in more pronounced seasonal signals (Fig. 11).

\section{Discussion}

347 The concept of using otolith chemical composition for age estimation is in its infancy (Hüssy et 348 al., 2016; Limburg et al., 2018) originating from decades of severe issues in age estimation of 349 Baltic cod. Heimbrand et al. (2020) hypothesized that chronological patterns in specific elements, 350 in particular $\mathrm{Mg}$ and $\mathrm{P}$, may be used for age estimation in fish. The present study is the first of its 351 kind, providing validation of this hypothesis that certain chemical elements are in fact incorporated 352 into the otolith in an annually recurring pattern which would make them useful as tool for age 353 estimation. We provided evidence that the chronological records of otolith $\mathrm{P}$ concentrations 354 showed the highest consistency in seasonal variation over the years, with minima occurring in late 355 winter/early spring when water temperatures are coldest and a seasonal amplitude which is 356 considerably larger in western compared to eastern Baltic cod. In the following we will highlight 357 differences in chronological patterns between elements with different incorporation mechanisms, 358 discuss these patterns in the context of stock-specific environmental conditions and the elements 359 usefulness for age determination.

361 Seasonality in element patterns

362 Elements reflecting environmental concentrations - $\mathrm{Sr} \mathrm{Ba}, \mathrm{Pb}$ and $\mathrm{K}$ - do not show strong, 363 consistent seasonal patterns across fish sizes (reflected in both $D E C O D E$ and $T A B A C O D$ otoliths) 364 and stocks, with two exceptions: $\mathrm{Pb}$ in $D E C O D E$ and $\mathrm{Sr}$ in TABACOD otoliths. In DECODE 365 otoliths, increases in $\mathrm{Pb}$ in summer may be attributable to the juvenile cod's shallower vertical 
366 distribution (Oeberst, 2008; Pihl, 1982; Pihl and Ulmestrand, 1993) with associated high 367 consumption of benthic crustaceans (Hüssy et al., 1997) that exhibit seasonal patterns in $\mathrm{Pb}$, as 368 well as $\mathrm{Cu}$ and $\mathrm{Zn}$ (Swaileh and Adelung, 1995). In eastern TABACOD cod, there are nevertheless 369 weak signals that seemingly correspond to seasonal patterns in Sr. Evidence from a range of 370 species suggests that seasonal peaks in otolith Sr coincides with peak spawning (Clarke and 371 Friedland, 2004; Granzotto et al., 2003; Kalish, 1991; Sturrock et al., 2015) reflecting a change in 372 Sr availability in the blood plasma (Sturrock et al., 2015). However, in this study highest $\mathrm{Sr}$ 373 concentrations occur during winter, while the peak spawning time of eastern Baltic cod is in July 374 - August (Bleil et al., 2009; Wieland et al., 2000). The seasonal pattern in Sr can therefore not be 375 376 377 378 379 380 381 382 attributed to spawning as such. Given the Baltic Seas vertical stratification, where bottom water has a much higher salinity, seasonal migrations may contribute to a seasonal signal in otolith $\mathrm{Sr}$ concentration. Overall this study supports the hypothesis that elements that co-vary with environmental concentration are generally not useful for age estimation, at least for Baltic cod. Among the elements regulated by physiological processes, $\mathrm{P}$ varies consistently over the seasons in both validation samples with minima co-occurring with otolith zones without visible daily increments in $D E C O D E$ otoliths or, in the case of the TABACOD otoliths, in late winter/early spring. The amplitude in $\mathrm{P}$ is considerably larger in western compared to eastern Baltic cod corresponding to known stock-specific differences in growth rate (Bagge et al., 1994; McQueen et al., 2020) and experienced temperature amplitude, apparently with a smaller variation around the mean values in the western Baltic cod. Throughout the Baltic Sea, phosphate concentrations are low from April to September, presumably owing to a combination of increased primary production (Wulff and Rahm, 1988) coupled with a precipitation-related increase in P loading during fall/winter (Rolff et al., 2008) and recycling in the sediments in hypoxic areas (Viktorsson 
389 et al., 2013). The seasonal bio-availability of phosphorus in the environment is thus out of phase 390 with the P concentrations observed in the otoliths. $\mathrm{P}$ does therefore indeed seem to be a consistent 391 tracer of seasonally varying physiological activity and growth rates in Baltic cod. In $\mathrm{Cu}$ and $\mathrm{Zn}$, 392 element minima also co-occur with winter zones in individual DECODE otoliths - but these 393 signals disappear when profiles of fish are combined suggesting some variation in the timing of 394 minima among individuals. In $T A B A C O D$ otoliths, there seems to be no relation between minima 395 and time of the year either. This lack in seasonality in Baltic cod may be related to family-specific 396 incorporation mechanism, in that no such patterns occur in Osmeridae either (Limburg and Elfman, 397 2010), while Zn concentrations in families like Salmonidae and Esocidae are at a minimum in 398 winter (Friedrich and Halden, 2010; Halden and Friedrich, 2008; Halden et al., 2000; Limburg and 399 Elfman, 2010). Additionally, one should also bear in mind that the concentrations of these elements 400 are very low, with low signal to noise ratios. Evidently, $\mathrm{Cu}$ and $\mathrm{Zn}$ are therefore not suitable for 401 age estimation - at least for Baltic cod.

402 Seasonal signals with minima during winter/late spring are also evident in $\mathrm{Mg}$ and $\mathrm{Mn}$ for both $403 D E C O D E$ and especially $T A B A C O D$ otoliths. While element uptake in marine fish generally 404 occurs from the water (Doubleday et al., 2013; Walther and Thorrold, 2006), dietary Mg 405 enrichment results in increased otolith Mg (Shearer and Åsgård, 1992). There is also growing 406 evidence that otolith $\mathrm{Mg}$ is tied to metabolism (Limburg et al., 2018; Thomas and Swearer, 2019). 407 Variations in $\mathrm{Mg}$ therefore may represent dietary and metabolic processes. The present results 408 support a strong physiological component, presumably related to consumption, in the 409 incorporation of the two elements as suggested by Limburg et al. (2018) and Limburg and Casini 410 (2018). Mg was also, together with $\mathrm{P}$, identified as the element with the highest precision among 411 age readers using chemical profiles for ageing Baltic cod, with an agreement of $74 \%$ compared to 
$41250 \%$ for traditional ageing with coefficients of variation of $10 \%$ and $22 \%$ respectively (Heimbrand 413 et al., 2020). Otolith $\mathrm{Mn}$ on the other hand, reflects environmental concentrations of $\mathrm{Mn}^{2+}$ made 414 available during hypoxia, with some additional physiological regulation (Altenritter et al., 2018; 415 Limburg and Casini, 2018; Thomas and Swearer, 2019). In the Baltic Sea, hypoxia is known to 416 occur frequently in shallow coastal areas during summer/fall (Conley et al., 2001) in addition to 417 the persistent hypoxia in the deeper areas of the Bornholm Basin (Viktorsson, 2017). The seasonal 418 signals, particularly apparent in the eastern Baltic cod otoliths, seem thus to reflect exposure to 419 higher environmental Mn concentrations during the spawning season in summer (Bleil et al., 2009; 420 Wieland et al., 2000) spent in the deeper areas of the Bornholm Basin (Nielsen et al., 2013; Hüssy 421 et al., 2020a). The more irregular patterns in western Baltic cod otoliths may instead reflect 422 summer-residence in more ephemeral hypoxic areas (Funk et al., 2020).

424 Timing of seasonal patterns

425 Small, yet consistent differences between the two Baltic cod stocks are evident in the elemental 426 minima of $\mathrm{P}, \mathrm{Mg}$ and $\mathrm{Mn}$ in the otoliths of tagged TABACOD cod. In eastern Baltic cod, these 427 minima occur in March, but in western Baltic cod somewhat earlier - in January/February. 428 Maxima occur in October/November and August/September in western and eastern Baltic cod 429 respectively. In the following we will examine to what extent these stock-specific differences in 430 extremum formation are attributable to water temperature or fish growth.

431 Eastern Baltic cod: The coldest temperatures experienced by eastern Baltic cod occur during 432 March and highest temperatures in October - November, as data from archival tags have shown 433 (Hüssy et al., 2009, 2010; Righton et al., 2010; Hüssy et al., 2020a). Otolith growth modelling 434 suggests that otolith increment formation apparently ceases at temperatures $<5-6^{\circ} \mathrm{C}$. in $D E C O D E$ 
435 otoliths (Hüssy et al., 2010), occurring in March/April at the depths inhabited by cod at that time 436 of the year. In eastern Baltic cod, the seasonal temperature experienced is reflected in fish somatic 437 growth patterns as well. A recent paper examining growth from tagging programs across multiple 438 decades (1955 - 1970), found minima and peaks in growth rates in March and September 439 respectively (Mion et al., 2020). However, a corresponding analysis with TABACOD data was not 440 able to detect seasonal variations in somatic growth (Mion et al., in review), which suggests that 441 otolith P concentration is not only a function of somatic growth.

442 Western Baltic cod: Cod in the western Baltic sea experience the lowest and warmest water 443 temperatures in January/February and August - October respectively (MARNET, 2020). The 444 timing of elemental extremum formation thus corresponds with the temporal temperature patterns. 445 Also in western Baltic cod historic tagging data from 1965 - 1972 found seasonally varying 446 somatic growth (Borrmann and Berner, 1983; Berner and Borrmann, 1985). Borrmann and Berner 447 (1983) attributed the difference in winter minimum to the maturation/spawning cycle. Berner and 448 Borrman (1985) further noticed that seasonal minima in growth occurred in January in fast 449 growing cod, but first in mid-April in slow growing cod, attributing the disparity to different stock 450 origin of the tagged cod. A recent study on cod tagged on two artificial reefs in 2007-2015 found 451 minima and peaks in somatic growth to occur in May and November, respectively (McQueen et 452 al., 2019). Both minima and peaks in growth of this stock occur approximately 3 months after the 453 corresponding element and temperature extrema. The reason for this apparent shift in timing over 454 time are somewhat unclear, but could be related to analytical differences (historic growth not 455 calculated on length change of individuals but mean sizes at estimated age), tagging of different 456 stock components (local sub-structuring of cod stocks in coastal areas of the Baltic Sea (Wenne et 
457 al., 2020)), or a climate change driven increase in summer temperatures to above-optimal levels

458 for cod growth.

459 The seasonal growth patterns from tagging studies of the eastern stock thus mirror the elemental 460 patterns from this study very well, and support a close coupling between seasonal temperature, 461 consumption and growth (Campana et al., 1995; Mello and Rose, 2005; Pörtner et al., 2001; 462 Schwalme and Chouinard, 1999) and incorporation of P, Mg and Mn - where minima in elements 463 occur when water temperatures are coldest and growth slowest. The corresponding information 464 from the western stock on the other hand indicates that the coupling between these processes may 465 be influenced by a range of additional, and to date unknown, factors.

467 Correspondence between age and number of element minima

468 The most basic requirement for a new age estimation method to be applicable for stocks where 469 traditional age estimation is not possible, is that it provides age estimates that are accurate (without 470 bias) and with high precision. In the present study, the number of chemical minima in $\mathrm{P}, \mathrm{Zn}$ and $471 \mathrm{Mg}$ only corresponded with the fish's known age in approximately $45-50 \%$ of the samples. Under472 estimation of the number of minima was largely attributable to the fact that extremum detection 473 methods need sufficient measurements on either side of the extremum in order to be able to identify 474 it correctly. Taking account for these missing minima at the edge of the otolith increased the 475 correspondence between known age and chemistry-derived age to approximately $80 \%$. One way 476 to avoid this issue in the future would be to select otoliths sampled just after the main growth 477 season between summer and early winter (and not at the coldest time of the year as the DECODE 478 samples in this study), giving the otoliths time to add a new growth increment. Over-estimation on 479 the other hand occurred in fish with sub-seasonal element cycles, even if these are often less 
480 prominent compared to the true seasonal signals. It is thus clear that the selection of a single 481 combination of settings for profile smoothing and extremum detection may lessen the accuracy of 482 the chemical method. Particularly so in a stock with large variability in behaviour between 483 individuals that may cause sub-seasonal patterns in temperature experience like the eastern Baltic 484 cod (Hüssy et al., 2009; Nielsen et al., 2013). In order to obtain an individual's correct age, visual 485 examination of the element profiles to identify potentially missing/superfluous extrema is 486 recommended.

487

488 Conclusion and future perspective

489 This study has shown that among the elements that are co-factors in the organic matrix regulating 490 biomineralisation, only $\mathrm{P}$ shows consistent seasonal patterns in concentration across fish size and 491 stocks. Other elements under physiological control $(\mathrm{Cu}$ and $\mathrm{Zn})$ occur at concentrations that are 492 too low for reliable signal detection. $\mathrm{Mg}$ shows similar, albeit much weaker, patterns as $\mathrm{P}$, 493 suggesting that the physiological regulation is outweighing environmental control. Elements that 494 substitute for $\mathrm{Ca}$ or that are randomly trapped in the otolith crystal lattice $(\mathrm{Sr}, \mathrm{Ba}, \mathrm{K}, \mathrm{Pb})$ are poor 495 indicators of growth, and by inference, the age of the fish.

496 Chronological patterns in P may thus have the potential to supplant/supplement traditional age 497 estimation or to guide the visual identification of translucent and opaque otolith patterns used in 498 traditional age estimation. Particularly in otoliths with discrepancies in interpretation between 499 readers such as the eastern Baltic cod, the microchemistry-based approach would improve the 500 accuracy of age estimates.

501 In all elements, inter-individual variation was considerable despite the application of 502 standardization routines. Studies that explore the environmental and/or biological drivers behind 
503 these inter-individual variations in absolute element concentrations as well as sub-seasonal pattern

504 formations based on targeted laboratory experiments and especially information from electronic 505 archival tags linked with chemical composition (Morita et al., 2013) are necessary to understand 506 the physiological processes regulating element incorporation into the otolith and to improve the 507 reliability of microchemistry as a routine age estimation method. Heimbrand et al. (2020) 508 highlighted that patterns of $\mathrm{P}$ were more pronounced in older individuals, while $\mathrm{Mg}$ patterns were 509 clearer in younger fish. This suggests that sexual maturation may influence the availability of 510 elements for incorporation into the otoliths. The present study corroborates these results, 511 suggesting that increased focus should be given to the impact of maturation and spawning on 512 otolith element concentrations and the impact of reduced seasonal temperature fluctuations in the 513 future.

514 Otolith biomineralisation is regulated by physiological and kinetic processes that may be expected 515 to be similar across fish taxa, with similar drivers of element incorporations (Hüssy et al., 2020b).

516 The extent to which the proposed use of chronological seasonal patterns in otolith P concentration 517 for age estimation is applicable to other species remains to be explored.

\section{Acknowledgements}

520 Thanks go to all technical staff involved in the collection and processing of samples used in this 521 study. TABACOD tagging was carried out by staff from the National Marine Fisheries Research 522 Institute, the Technical University of Denmark, the Swedish University of Agricultural Sciences 523 and the Thünen Institute of Baltic Sea Fisheries. Additional thanks to Kristian Ege Nielsen for the 524 chemical analyses of samples. 


\section{Competing interests}

527 The authors declare there are no competing interests.

528

529 Contributors' statement

530 KH: Conceptualization, Formal analysis, Writing - Original Draft, Project administration, 531 Supervision, Funding acquisition

532 MKJ: Methodology, Investigation, Data curation

533 TBT: Methodology, Data curation, Writing - Review \& Editing

534 BDH: Methodology, Data curation, Writing - Review \& Editing

535 TN: Methodology, Writing - Review \& Editing

536 KEL: Conceptualization, Writing - Review \& Editing, Funding acquisition

537 YH: Conceptualization, Writing - Review \& Editing

538 KMQ: Investigation, Data curation, Writing - Review \& Editing

539 SH: Investigation, Data curation, Writing - Review \& Editing

540 UK: Investigation, Writing - Review \& Editing, Funding acquisition

541 MC: Investigation, Writing - Review \& Editing, Funding acquisition

542 MM: Investigation, Data curation, Writing - Review \& Editing

543 KR: Investigation, Data curation, Writing - Review \& Editing, Funding acquisition

545 Funding statement

546 This study was funded by BalticSea2020 (http://balticsea2020.org) through the project Tagging 547 Baltic Cod (TABACOD). Financial support is also acknowledged from the Danish Ministry for 548 Environment and Food and the European Maritime Fisheries Fond [grant No. 33113-B-17-092], 
549 the Swedish Research Council Formas [grant No. 2015-865] and the U.S. National Science 550 Foundation under Grant [grant No. OCE-1923965].

551

552 Data availability statement

553 The data upon which this study is based originate from the TABACOD project. In the Cooperation 554 Agreement of that project it has been stated that data from TABACOD will be made publicly 555 available 5 years after the termination of the project (31/05/2025), in order to ensure project 556 participants sufficient time to publish ongoing work. During the 5-year embargo period, access to 557 data may be given by contacting the corresponding author.

\section{References}

560 Altenritter, M.E., and Walther, B.D. 2019. The Legacy of Hypoxia: Tracking Carryover Effects of 561 Low Oxygen Exposure in a Demersal Fish Using Geochemical Tracers. Trans. Am. Fish. 562 563 564 565 566 567 568 569 Soc. 148(3): 569-583. doi:10.1002/tafs.10159.

Altenritter, M., Cohuo, A., and Walther, B. 2018. Proportions of demersal fish exposed to sublethal hypoxia revealed by otolith chemistry. Mar. Ecol. Prog. Ser. 589: 193-208. doi:10.3354/meps 12469 .

Bagge, O., Thurow, F., Steffensen, E., and Bay, J. 1994. The Baltic cod. Dana 10: 1-28.

Baranova, T., Müller-Karulis, B., Sics, I., and Plikshs, M. 2011. Changes in the annual life cycle of eastern Baltic cod during 1950-2010. ICES CM 2011/R:10.

Beckman, D., and Wilson, C.A. 1995. Seasonal timing of opaque zone formation in fish otoliths. In Recent Developments in Fish Otolith Research. Edited by D.H. Secor, J.M. Dean, and S.E. Campana. University of South Carolina Press, Columbia, SC. pp. 27-44. 
572 Berner, M. 1968. Einige orientierende Untersuchungen and den Otolithen des Dorsches (Gadus 573 morhua L.) aus verschiedenen Regionen der Ostsee. Fisch. Forsch. 6: 77-86.

574 Berner, M., and Borrmann, H. 1985. Zum saisonalen Längenwachstum des Dorsches der 575 Mecklenburger Bucht nach Wiederfangdaten von Markierungsexperimenten und 576 Bestandsvergleichen. Fisch. Forsch. 22(1): 63-69.

577 Bleil, M., Oeberst, R., and Urrutia, P. 2009. Seasonal maturity development of Baltic cod in 578 different spawning areas: importance of the Arkona Sea for the summer spawning stock. J. 579 Appl. Ichthyol. 25(1): 10-17. doi:10.1111/j.1439-0426.2008.01172.x.

580 Borelli, G., Mayer-Gostan, N., Merle, P.L., Pontual, H., Boeuf, G., Allemand, D., and Payan, P. 581 2003. Composition of Biomineral Organic Matrices with Special Emphasis on Turbot (Psetta 582 maxima) Otolith and Endolymph. Calc. Tiss. Int. 72(6): 717-725. doi:10.1007/s00223-001583 2115-6.

584 Borrmann, H., and Berner, M. 1983. Zum saisonalen Längenwachstum des Arkonasee-Dorsches 585 nach Wiederfangdaten von Markierungsexperimenten. Fisch. Forsch. 23: 1-5.

586 Campana, S.E. 1999. Chemistry and composition of fish otoliths: pathways, mechanisms and 587 applications. Mar. Ecol. Prog. Ser. 188: 263-297. doi:10.3354/meps188263.

588 Campana, S.E. 2001. Accuracy, precision and quality control in age determination, including a 589 review of the use and abuse of age validation methods. J. Fish Biol. 59: 197-242. 590 doi:10.1111/j.1095-8649.2001.tb00127.x.

591 Campana, S.E., Mohn, R.K., Smith, S.J., and Chouinard, G.A. 1995. Spatial implications of a 592 temperature based growth model for Atlantic cod (Gadus morhua) off the eastern coast of Canada. Can. J. Fish. Aquat. Sci. 52: 2445-2456.

594 Clarke, L.M., and Friedland, K.D. 2004. Influence of growth and temperature on strontium 
595 deposition in the otoliths of Atlantic salmon. J. Fish Biol. 65(3): 744-759. 596 doi:10.1111/j.0022-1112.2004.00480.x.

597 Conley, D.J., Carestensen, J., Aigars, J., Bonsdorff, E., Eremina, T., Haahti, B.-M., Humborg, C., 598 Jonssibm P., Kotta, J., Lännegren, C., Larsson, U., Maximov, A., Rodrigues Medina, M., 599 Lysiak-Pastuszak, E., Remeikaite-Nikiene, N., Walve, J., Wilhelms, S., and Zillén, L. 2001. 600 Hypoxia is increasing in the coastal zone of the Baltic Sea. Env. Sci. Tech. 45: 6777-6783. 601 doi:10.1021/es201212r.

602 Constantine, W. 2007. Local maxima $[\mathrm{R}$ package]. Available from: 603 https://www.rdocumentation.org/packages/splus2R/versions/1.0-1/topics/peaks [accessed 17 $604 \quad$ August 2020].

605 DECODE. 2009. ImproveD mEthodology for Baltic COD Age Estimation [Report]. Available 606 from: http://ec.europa.eu/fisheries/documentation/studies/cod_age_en.pdf.

607 Doubleday, Z.A., Harris, H.H., Izzo, C., and Gillanders, B.M. 2014. Strontium randomly 608 substituting for calcium in fish otolith aragonite. Anal. Chem. 86(1): 865-869. 609 doi:10.1021/ac4034278.

610 Doubleday, Z., Izzo, C., Woodcock, S., and Gillanders, B.M. 2013. Relative contribution of water 611 and diet to otolith chemistry in freshwater fish. Aquat. Biol. 18(3), 271-280. 612 doi:10.3354/ab00511.

613 Eero, M., Hjelm, J., Behrens, J., Buchmann, K., Cardinale, M., Casini, M., Gasyukov, P., 614 Holmgren, N., Horbowy, J., Hüssy, K., Kirkegaard, E., Kornilovs, G., Krumme, U., Köster, 615 F.W., Oeberst, R., Plikshs, M., Radtke, K., Raid, T., Schmidt, J., Tomczak, M.T., Vinther, 616 M., Zimmermann, C., and Storr-Paulsen, M. 2015. Eastern Baltic cod in distress: Biological 617 changes and challenges for stock assessment. ICES J. Mar. Sci. 72(8), 2180-2186. 
doi:10.1093/icesjms/fsv109.

619 Friedrich, L.A., and Halden, N.M. 2010. Determining Exposure History of Northern Pike and 620

621 Walleye to Tailings Effluence Using Trace Metal Uptake in Otoliths. Env. Sci. Tech. 44(5): 1551-1558. doi:10.1021/es903261q.

622 Funk, S., Krumme, U., Temming, A., and Möllmann, C. 2020.Gillnet fishers’ knowledge reveals 623 seasonality in depth and habitat use of cod (Gadus morhua) in the Western Baltic Sea. ICES 624 J. Mar. Sci. doi:10.1093/icesjms/fsaa071.

625 Granzotto, A., Franceschini, G., Malavasi, S., Molin, G., Pranovi, F., and Torricelli, P. 2003. 626 Marginal increment analysis and $\mathrm{Sr} / \mathrm{Ca}$ ratio in otoliths of the grass goby, Zosterisessor ophiocephalus. It. J. Zool. 70(1): 5-11. doi:10.1080/11250000309356489.

628 Halden, N.M., and Friedrich, L.A. 2008. Trace-element distributions in fish otoliths: natural 629 markers of life histories, environmental conditions and exposure to tailings effluence. Min. 630 631 Halden, N.M., Mejia, S.R., Babaluk, J.A., Reist, J.D., Kristofferson, A.H., Campbell, J.L., and 632 633 634 Teesdale, W.J. 2000. Oscillatory zinc distribution in Arctic char (Salvelinus alpinus) otoliths: The result of biology or environment? Fish. Res. 46(1-3): 289-298. doi:10.1016/S01657836(00)00154-5.

635 Heimbrand, Y., Limburg, K.E., Hüssy, K., Casini, M., Sjöberg, R., Palmén Bratt, A., Levinsky, S.636 E., Karpushevskaia, A., Radtke, K., and Öhlund, J. 2020. Seeking the True Time: Exploring 637 Otolith Chemistry as an Age-Determination Tool. J. Fish Biol. jfb.14422. 638 doi:10.1111/jfb.14422.

639 Hemmer-Hansen, J., Hüssy, K., Baktoft, H., Huwer, B., Bekkevold, D., Haslob, H., Herrmann, J.640 P., Hinrichsen, H.-H., Krumme, U., Mosegaard, H., Nielsen, E.E., Reusch, T.B. H, Storr- 
641 Paulsen, M., Velasco, A., von Dewitz, B., Dierking, J., Eero, M. 2019. Genetic analyses

642 reveal complex dynamics within a marine fish management area. Evol. Appl. doi:12: 830_-

643 844.

644 Høie, H., and Folkvord, A. 2006. Estimating the timing of growth rings in Atlantic cod otoliths 645 646 using stable oxygen isotopes. J. Fish Biol. 68(3): 826-837. doi:10.1111/j.00221112.2006.00957.x.

647 Hüssy, K, Nielsen, B., Mosegaard, H., and Clausen, L. 2009. Using data storage tags to link otolith 648 macro- structure in Baltic cod Gadus morhua with environmental conditions. Mar. Ecol. 649 Prog. Ser. 378: 161-170. doi:10.3354/meps07876.

650 Hüssy, K. 2010. Why is age determination of Baltic cod (Gadus morhua) so difficult? ICES J. Mar. 651 Sci. 67(6): 1198-1205. doi:10.1093/icesjms/fsq023.

652 Hüssy, K., Casini, M., Haase, S., Hilvarsson, A., Horbowy, J., Krüger-Johnsen, M., Krumme, U., 653 Limburg, K. E., McQueen, K., Mion, M., Olesen, H. J., and Radtke, K. 2020b. Tagging Baltic 654 655 656 657 Cod - TABACOD. Eastern Baltic cod: Solving the ageing and stock assessment problems with combined state-of-the-art tagging methods. DTU Aqua Report no. 368-2020. National Institute of Aquatic Resources, Technical University of Denmark. 64 pp. ISBN:978-87-7481290-6.

658 Hüssy, K., Gröger, J., Heidemann, F., Hinrichsen, H.-H., and Marohn, L. 2016. Slave to the rhythm: 659 660 Seasonal signals in otolith microchemistry reveal age of eastern Baltic cod (Gadus morhua).

661 Hüssy, K., Hinrichsen, H.-H, Fey, D.P., Walther, Y., and Velasco, A. 2010. The use of otolith 662 663 microstructure to estimate age in adult Atlantic cod Gadus morhua. J. Fish Biol. 76(7), 16401654. doi:10.1111/j.1095-8649.2010.02602.x. 
664 Hüssy, K., St.John, M.A., and Böttcher, U. 1997. Food resource utilization by juvenile Baltic cod 665 666 667 668 Gadus morhua: A mechanism potentially influencing recruitment success at the demersal juvenile stage? Mar. Ecol. Prog. Ser. 155: 199-208. doi:10.3354/meps155199.

Hüssy, Karin, Eero, M., and Radtke, K. 2018. Faster or slower: has growth of eastern Baltic cod changed? Mar. Biol. Res. 14(6): 598-609. doi:10.1080/17451000.2018.1502446.

669 Hüssy, Karin, Limburg, K.E., de Pontual, H., Thomas, O.R.B., Cook, P.K., Heimbrand, Y., Blass, 670 M., and Sturrock, A.M. 2020. Trace Element Patterns in Otoliths: The Role of 671 Biomineralization. Rev. Fish. Sci. Aquacult. 1-33. doi:10.1080/23308249.2020.1760204.

672 Hüssy, Karin, Radtke, K., Plikshs, M., Oeberst, R., Baranova, T., Krumme, U., Sjöberg, R., 673 Walther, Y., and Mosegaard, H. 2016. Challenging ICES age estimation protocols: lessons 674 learned from the eastern Baltic cod stock. ICES J. Mar. Sci. 73(9): 2138-2149. 675 doi:10.1093/icesjms/fsw107.

676 ICES. 2014. Report of the Baltic Fisheries Assessment Working Group (WGBFAS). 3-10 April 677 2014 ICES HQ. Copenhagen, Denmark. ICES CM 2014/ ACOM:10.

678 ICES. 2015. Report of the Benchmark Workshop on Baltic Cod Stocks (WKBALTCOD). 2-6 679 March 2015, Rostock, Germany. ICES CM 2015/ACOM:35.

680 Izzo, C., Doubleday, Z.A., and Gillanders, B.M. 2016. Where do elements bind within the otoliths 681 of fish? Mar. Fresh. Res. 67(7): 1072-1076. doi:10.1071/MF15064.

682 Jochum, K.P., Weis, U., Schwager, B., Stoll, B., Wilson, S.A., Haug, G.H., Andreae, M.O., and 683 Enzweiler, J. 2016. Reference Values Following ISO Guidelines for Frequently Requested 684 Rock Reference Materials. Geost. Geoanal. Res. 40(3): 333-350. doi:10.1111/j.17516859 908X.2015.00392.x.

686 Jochum, K.P., Weis, U., Stoll, B., Kuzmin, D., Yang, Q., Raczek, I., Jacob, D.E., Stracke, A., 
687 Birbaum, K., Frick, D.A., Günther, D., and Enzweiler, J. 2011. Determination of Reference 688 Values for NIST SRM 610-617 Glasses Following ISO Guidelines. Geost. Geoanal. Res. 689 35(4): 397-429. doi:10.1111/j.1751-908X.2011.00120.x.

690 Kalish, J.M. 1991. Determinants of otolith chemistry: seasonal variation in the composition of 691 blood plasma, endolymph and otoliths of bearded rock cod Pseudophycis barbatus. Mar. 692 Ecol. Prog. Ser. 74: 137-159. doi: 10.2307/24825820.

693 Kraus, R. T., and Secor, D. H. 2004. Incorporation of strontium into otoliths of an estuarine fish. J. 694 Exp. Mar. Biol. Ecol. 302(1): 85-106. doi:10.1016/J.JEMBE.2003.10.004.

695 Limburg, K.E., Olson, C., Walther, Y., Dale, D., Slomo, C.P., and Høie, H. 2011. Tracking Baltic 696 hypoxia and cod migration over millennia with natural tags. Proc. Nat. Acad. Sci. US 108(22), $697 \quad$ E177-E182. doi:10.1073/pnas.1100684108

698 Limburg, K.E., and Casini, M. 2018. Effect of Marine Hypoxia on Baltic Sea Cod Gadus morhua: 699 Evidence From Otolith Chemical Proxies. Front. Mar. Sci. 5: 482. $700 \quad$ doi:10.3389/fmars.2018.00482.

701 Limburg, K.E., and Elfman, M. 2010. Patterns and magnitude of Zn:Ca in otoliths support the recent 702 phylogenetic typology of Salmoniformes and their sister groups. Can. J. Fish. Aquat. Sci. 703 67(4): 597-604. doi:10.1139/f10-014.

704 Limburg, K.E., Wuenschel, M.J., Hüssy, K., Heimbrand, Y., and Samson, M. 2018. Making the 705 Otolith Magnesium Chemical Calendar-Clock Tick: Plausible Mechanism and Empirical 706 Evidence. Rev. Fish. Sci. Aquacult. 26(4), 479-493. doi:10.1080/23308249.2018.1458817 707 MARNET. 2020. Data of the automated measuring stations (MARNET) [Data repository]. 708 Available from: https://www.io-warnemuende.de/marnet-arkona-sea.html [accessed 19 April 2020]. 
710 McQueen, K., Casini, M., Dolk, B., Haase, S., Hemmer-Hansen, J., Hilvarsson, A., Hüssy, K., 711 Mion, M., Mohr, T., Radtke, K., Schade, F.M., Schulz, N., and Krumme, U. 2020. Regional and stock-specific differences in contemporary growth of Baltic cod revealed through tagrecapture data. ICES J. Mar. Sci. doi:10.1093/icesjms/fsaa104.

McQueen, K., Eveson, J.P., Dolk, B., Lorenz, T., Mohr, T., Schade, F.M., and Krumme, U. 2019. Growth of cod (Gadus morhua) in the western Baltic Sea: estimating improved growth parameters from tag-recapture data. Can. J. Fish. Aquat. Sci. 76(8): 1326-1337. doi:10.1139/cjfas-2018-0081.

Mello, L.G.S., and Rose, G.A. 2005. Seasonal growth of Atlantic cod: effects of temperature, feeding and reproduction. J. Fish Biol. 67(1): 149-170. doi:10.1111/j.00221112.2005.00721.x.

Miller, M.B., Clough, A.M., Batson, J.N., and Vachet, R.W. 2006. Transition metal binding to cod otolith proteins. J. Exp. Mar. Biol. Ecol. 329(1): 135-143. doi:10.1016/J.JEMBE.2005.08.016.

724 Mion, M., Haase, S., Hemmer-Hansen, J., Hilvarsson, A., Hüssy, K., Krüger-Johnsen, M., Krumme, 725 U., McQueen, K., Plikshs, M., Radtke, K., Schade, F.M., Vitale, F., Casini, M. Multidecadal 726 changes in fish growth rates estimated from tagging data: a case study from the Eastern Baltic cod stock. Fish Fish. (in review, Manuscript ID FaF-20-Jun-OA-158).

Mion, M., Hilvarsson, A., Hüssy, K., Krumme, U., Krüger-Johnsen, M., McQueen, K., Mohamed, E., Motyka, R., Orio, A., Plikshs, M., Radtke, K., and Casini, M. 2020. Historical growth of Eastern Baltic cod (Gadus morhua): Setting a baseline with international tagging data. Fish. Res. 223: 105442. doi:10.1016/j.fishres.2019.105442.

732 Mohan, J., and Walther, B. 2016. Out of breath and hungry: natural tags reveal trophic resilience 
733 of Atlantic croaker to hypoxia exposure. Mar. Ecol. Prog. Ser. 560: $207-221$. doi:10.3354/meps 11934 .

735 Morita, K., Morita, S. H., Nagasawa, T., and Kuroki, M. 2013. Migratory patterns of anadromous 736 white-spotted charr Salvelinus leucomaenis in Eastern Hokkaido, Japan: The solution to a 737 mystery? J. Ichthyol. 53(10): 809-819. doi:10.1134/S0032945213100068.

738 Nielsen, B., Hüssy, K., Neuenfeldt, S., Tomkiewicz, J., Behrens, J.W., and Andersen, K.H. 2013. 739 Individual behaviour of Baltic cod Gadus morhua in relation to sex and reproductive state. Aquat. Biol. 18(2): 197-207. doi:10.3354/ab00505.

741 Oeberst, R. 2008. Distribution pattern of cod and flounder in the Baltic Sea based on international coordinated trawl surveys. ICES CM, 2008/J:09(28).

743 Payan, P., de Pontual, H., Bœuf, G., and Mayer-Gostan, N. 2004. Endolymph chemistry and otolith 744 growth in fish. Com. Rend. Pale. 3(6-7): 535-547. doi:10.1016/J.CRPV.2004.07.013.

745 Pihl, L. and Ulmestrand, M. 1993. Migration patterns of juvenile cod (Gadus morhua) on the 746 Swedish west coast. ICES J. Mar. Sci. 50(1): 63-70.

747 Pihl, L. 1982. Food intake of young cod and flounder in a shallow bay on the Swedish west coast. 748 Neth. J. Sea Res. 15(3), 419-432.

749 Pörtner, H. O., Berdal, B., Blust, R., Brix, O., Colosimo, A., De Wachter, B., Giuliani, A., Johansen, 750 T., Fischer, T., Knust, R., Lannig, G., Naevdal, G., Nedenes, A., Nyhammer, G., Sartoris, F. 751 J., Serendero, I., Sirabella, P., Thorkildsen, S. and Zakhartsev, M. 2001. Climate induced 752 temperature effects on growth performance, fecundity and recruitment in marine fish: 753 Developing a hypothesis for cause and effect relationships in Atlantic cod (Gadus morhua) 754 and common eelpout (Zoarces viviparus). Cont. Shelf Res. 21(18-19): 1975-1997. 755 doi:10.1016/S0278-4343(01)00038-3. 
756 R Development Core Team. 2020. R: A Language and Environment for Statistical Computing. 757

Rolff, C., Elmgren, R., and Voss, M. 2008. Deposition of nitrogen and phosphorus on the Baltic Sea: seasonal patterns and nitrogen isotope composition. Biogeosci. Disc. 5:1657-1667. doi: biogeosciences-discuss.net/5/3013/2008.

Schade, F., Weist, P., and Krumme, U. 2019. Evaluation of four stock discrimination methods to assign individuals from mixed-stock fisheries using genetically validated baseline samples. Mar. Ecol. Prog. Ser. 627: 125-139. doi: 10.3354/meps13061.

Schwalme, K., and Chouinard, G.A. 1999. Seasonal dynamics in feeding, organ weights, and reproductive maturation of Atlantic cod (Gadus morhua) in the southern Gulf of St. Lawrence. ICES J. Mar. Sci. 56: 303-319. doi: 10.1006/jmsc.1999.0458.

Serre, S.H., Hüssy, K., Nielsen, K.E., Fink-Jensen, P., and Thomsen, T.B. 2018. Analysis of cod otolith microchemistry by continuous line transects using LA-ICP-MS. Geol. Surv. Den. Greenl. Bull. 41: 91-94. doi:1604-8156. 
779 Seyama, H., Edmonds, J.S., Moran, M.J., Shibata, Y., Soma, M., and Morita, M. 1991. Periodicity 780 in fish otolith Sr, Na, and K corresponds with visual banding. Expri. 47: 1193-1196.

781 Shearer, K.D., and Åsgård, T. 1992. The effect of water-borne magnesium on the dietary 782 783 magnesium requirement of the rainbow trout (Oncorhynchus mykiss). Fish Physiol. Biochem. 9(5-6): 387-392. doi:10.1007/BF02274219.

784 785 786 787 788 789 790 791 792 793 794 795 796 797 798 799 800 801

Siskey, M.R., Lyubchich, V., Liang, D., Piccoli, P.M., and Secor, D.H. 2016. Periodicity of strontium: Calcium across annuli further validates otolith-ageing for Atlantic bluefin tuna (Thunnus thynnus). Fish. Res. 177: 13-17. doi:10.1016/j.fishres.2016.01.004.

Sturrock, A.M., Hunter, E., Milton, J.A., Johnson, R.C., Waring, C.P., and Trueman, C.N. 2015. Quantifying physiological influences on otolith microchemistry. Met. Ecol. Evol. 6(7): 806816. doi:10.1111/2041-210X.12381.

Sturrock, A.M., Trueman, C.N., Darnaude, A.M., and Hunter, E. 2012. Can otolith elemental chemistry retrospectively track migrations in fully marine fishes? J. Fish Biol. 81(2): 766795. doi:10.1111/j.1095-8649.2012.03372.x.

Swaileh, K.M., and Adelung, D. 1995. Effect of body size and season on the concentrations of Cu, $\mathrm{Cd}, \mathrm{Pb}$ and $\mathrm{Zn}$ in Diastylis rathkei (kröyer) (Crustacea: Cumacea) from Kiel Bay, Western Baltic. Mar. Poll. Bul. 31(1-3): 103-107. doi:10.1016/0025-326X(94)00258-B.

Thomas, O.R.B., and Swearer, S.E. 2019. Otolith Biochemistry-A Review. Rev. Fish. Sci. Aquac. 27(4): 458-489. doi:10.1080/23308249.2019.1627285.

Thomas, O.R.B., Ganio, K., Roberts, B.R., and Swearer, S.E. 2017. Trace element-protein interactions in endolymph from the inner ear of fish: implications for environmental reconstructions using fish otolith chemistry. Metall. 9(3): 239-249. doi:10.1039/C6MT00189K. 
802 Tomás, J., Geffen, A.J., Millner, R.S., Piñeiro, C.G and Tserpes, G. 2006. Elemental composition 803 of otolith growth marks in three geographically separated populations of European hake 804 (Merluccius merluccius). Mar. Biol. 148: 1399-1413. doi: 10.1007/s00227-005-0171-6.

805 Viktorsson L. 2017. Hydrography and oxygen in the deep basins. HELCOM Baltic Sea 806 Environment Fact Sheets (BSEFS). pp 7 [Report] Available from: https://helcom.fi/wp807 content/uploads/2020/07/BSEFS-Sea-Surface-Temperature-in-the-Baltic-Sea-2018.pdf $808 \quad$ [accessed 25 August 2020].

809 Viktorsson, L., Ekeroth, N., Nilsson, M., Kononets, M., and Hall, P.O.J. 2013. Phosphorus 810 recycling in sediments of the central Baltic Sea. Biogeosci. 10: 3901-3916. doi:10.5194/bg-

812 Walther, B.D., and Thorrold, S.R. 2006. Water, not food, contributes the majority of strontium and 813 barium deposited in the otoliths of a marine fish. Mar. Ecol. Prog. Ser. 311: 125-130. doi:10.3354/meps311125.

815 Weidman, C.R., and Millner, R. 2000. High-resolution stable isotope records from North Atlantic 816 cod. Fish. Res. 46(1-3): 327-342. doi:10.1016/S0165-7836(00)00157-0.

817 Wenne, R., Bernaś, R., Kijewska, A., Pócwierz-Kotus, A., Strand, J., Petereit, C., Plauska, K., Sics, 818 I., Árnyasi, M., and Kent, M.P. 2020. SNP genotyping reveals substructuring in weakly 819 differentiated populations of Atlantic cod (Gadus morhua) from diverse environments in the 820 Baltic Sea. Sci. Rep. 10: 9738. doi: s41598-020-66518-4.

821 Wieland, K., Jarre-Teichmann, A., and Horbowa, K. 2000. Changes in the timing of spawning of 822 Baltic cod: possible causes and implications for recruitment. ICES J. Mar. Sci. 57(2): 452823 464. doi:1006/jmsc.1999.0522.

824 Wulff, F., and Rahm, L. 1988. Long-term, seasonal and spatial variations of nitrogen, phosphorus 
825 and silicate in the Baltic; An overview. Mer. Env. Res. 26(1):19-37. doi:10.1016/0141$826 \quad 1136(88) 90032-3$.

827 


\section{$828 \quad$ Figure captions}

829

830 Fig. 1. Map of the locations of cod from three different samples used in this study. Green symbols:

831 Known-age samples of Baltic cod from the "ImproveD mEthodology for Baltic COD Age

832 Estimation" (DECODE) project where age was obtained from patterns in daily otolith increment 833 widths (varying size indicative of sample size). Blue and red symbols: Samples of recaptured 834 Baltic cod from the international tagging project "Tagging Baltic Cod" (TABACOD), where 835 symbols show the recapture locations of tagged cod (eastern Baltic cod $=$ blue symbols; western 836 Baltic $\operatorname{cod}=$ red symbols). Black symbols: Samples of cod from the Kattegat, which have a high 837 contrast between otolith growth zones and therefore are used as test group to identify the best 838 approach for the analyses of element profiles. Numbers identify ICES Subdivisions (SD), where 839 SD 21: Kattegat, SD 22: Belt Sea, SD 23: Sound, SD 24: Arkona Sea, SD 25 Bornholm Sea, SD 840 26: Gdansk Bay and SD 28: Gotland Basin. The area consists of three management areas: Kattegat 841 (SD 21), western Baltic Sea (SD 22 - 24) and eastern Baltic Sea (SD 25 - 32). Map created using 842 the "maps" package ver. 3.3.0 of "R".

844 Fig. 2. Transversal section of an otolith from a 4-year old cod caught in December 2010 in Kattegat 845 from the test sample (TEST) characterized by high contrast between seasonal translucent and 846 opaque zones with concurrent high age estimation precision and well established ageing protocols. 847 TEST samples were used to identify the best setting for profile smoothing and peak detection. 848 Otolith section is viewed under reflected light, with superimposed elemental profile of phosphorus 849 (as $\mathrm{P} / \mathrm{Ca}$ ratio) from the nucleus to the dorsal otolith edge and translucent seasonal growth zones 850 indicated by grey vertical bars. 
852 Fig. 3. Transversal section of otolith of a 3-year old Baltic cod from the first validation collection, 853 the $D E C O D E$ samples, where age was obtained from patterns in daily otolith increment widths, 854 viewed under reflected light (bottom right), where the black box indicates the otolith area viewed 855 under 20x magnification and transmitted light (middle image). In this image, white dots indicate 856 daily increments prior to and after a zone with no visible increments. The profile of daily increment 857 widths from core to otolith edge (top left) shows how "winter zones" were identified. Winter zones 858 (WZ) are indicated with arrows, where the distance of the midpoint of each zone to the core is the 859 measurement used in the present analyses. Note that the last $W Z$ has just started to form at the edge 860 of the otolith and can therefore not be measured. Since the cod was caught in February and new 861 growth zones are counted from the $1^{\text {st }}$ January, this last zone corresponding to the edge, is counted 862 when estimating the age of the fish. The arrows in the images of otolith cross section and magnified 863 otolith zone showing daily increments correspond to the $W Z$ identified in daily increment profile 864 (top left).

866 Fig. 4. Transversal section of a tagged eastern Baltic cod otolith from the second validation sample, 867 the $T A B A C O D$ samples consisting of tagged and recaptured cod from the from the international 868 tagging project "Tagging Baltic Cod", viewed under reflected light with the position of the laser 869 transect indicated with a broken black line. The same otolith is shown under UV light showing the 870 green fluorescent TET mark induced at release, where the part of the profile used in this study is 871 indicated with a solid black line on both images. The cod was released at 54.60 $\mathrm{N}$ and 13.42 E on 872 the $03 / 11 / 2017$ at a length of $263 \mathrm{~mm}$ and recaptured at a length of $462 \mathrm{~mm}$ at $54.69 \mathrm{~N}$ and $13.19 \mathrm{E}$ 873 on the $19 / 06 / 2019$ after 593 days at liberty. 40 
875 Fig. 5. Element profiles of a 4-year old, $290 \mathrm{~mm}$ long, male Baltic cod from the first validation 876 collection, the DECODE samples, where age was obtained from patterns in daily otolith increment 877 widths, including an image of the corresponding otolith viewed under reflected light. Profiles show 878 relative element concentrations (Element:Ca ratios divided by the profile mean for each element) 879 where data are loess smoothed means and confidence interval bands in relation to distance to the 880 at the beginning of the profiles.

Fig. 6. Relationship between minima in the chemical profiles (Min) for all elements separately in relation to winter zones $(W Z)$ identified in the daily increment patterns of Baltic cod from the first 891 validation collection, the DECODE samples, where age was obtained from patterns in daily otolith increment widths. Colours indicate consecutive number of Min and corresponding WZ identified. Black represents the first element $M i n$ and $W Z$, red and green represent the subsequent second and 894 third Min and WZ. Incorporation mechanisms of the elements, i.e. whether element incorporation 895 is expected to depend on environmental concentration, physiology or a combination of both, is 896 indicated above each column.. 
Fig. 7. Frequency distributions of the difference between known age identified from daily increment patterns and chemical age from the number of profile minima ( WZ - Min) by element in Baltic cod from the first validation collection, the $D E C O D E$ samples, where age was obtained from patterns in daily otolith increment widths. Incorporation mechanisms of the elements, i.e. whether element incorporation is expected to depend on environmental concentration, physiology or a combination of both, is indicated above each column..

Fig. 8. Element profiles of a tagged and recaptured female eastern Baltic cod from the $T A B A C O D$ validation samples from the international tagging project "Tagging Baltic Cod" with 927 days at liberty, including an image of the corresponding otolith view under reflected light (black bar indicates tagging period). Released on $14 / 11 / 2016,54.574 \mathrm{~N}, 13.825 \mathrm{E}$ at a length of $370 \mathrm{~mm}$; Recaptured on 30/05/2019, 55.377N, 15.647E at a length of $471 \mathrm{~mm}$. Profiles show relative element concentrations (Element:Ca ratios divided by the profile mean for each element), from the TET mark to the otolith edge. Data are shown with loess smoothed means and confidence interval bands in relation to distance to the core. Element minima $($ Min $)=$ blue symbols, element maxima $(\operatorname{Max})=$ red symbols, vertical lines from Min to x-axis are shown to facilitate the identification of 914 the time of the year corresponding to the extrema. Incorporation mechanisms of the elements is 915 indicated above each column. Min in P occur in April in the years 2018 and 2019 and apparently 916 somewhat earlier in 2017 , albeit this minimum is difficult to estimate precisely owing to the limited 917 data points between profile start and $\mathrm{Min}_{2017}$. Min in $\mathrm{Mg}$ follow the same pattern but with a delay 918 of approximately 1 month. Incorporation mechanisms of the elements, i.e. whether element 
919 incorporation is expected to depend on environmental concentration, physiology or a combination 920 of both, is indicated above each column.

922 Fig. 9. Elements where incorporation depends entirely on environmental concentration. Profiles 923 are from the second validation samples, the TABACOD samples of tagged and recaptured Baltic 924 cod with more than 180 days at liberty, from the TET mark to the otolith edge, in relation to date 925 of incorporation. Left panel $=$ eastern Baltic cod, right panes $=$ western Baltic cod. Data shown are 926 relative element concentrations (Element:Ca ratios divided by the profile mean for each element) 927 with loess smoothed means and confidence interval bands. Minima $($ Min $)=$ blue symbols, maxima $928($ Max $)=$ red symbols. Vertical lines from extrema to $\mathrm{x}$-axis are shown to facilitate identification 929 the time of the year corresponding to the extrema.

931 Fig. 10. Elements where incorporation is regulated by an interaction of environmental 932 concentration and physiological processes. Profiles are from the second validation samples, the 933 TABACOD samples of tagged and recaptured Baltic cod with more than 180 days at liberty, from 934 the TET mark to the otolith edge, in relation to date of incorporation. Left panel = eastern Baltic 935 cod, right panes = western Baltic cod. Data shown are relative element concentrations (Element:Ca 936 ratios divided by the profile mean for each element) with loess smoothed means and confidence 937 interval bands. Minima $($ Min $)=$ blue symbols, maxima $($ Max $)=$ red symbols. Vertical lines from 938 extrema to $\mathrm{x}$-axis are shown to facilitate identification the time of the year corresponding to the 939 extrema. 
941 Fig. 11. Elements where incorporation is regulated entirely by physiological processes. Profiles 942 are from the second validation samples, the TABACOD samples of tagged and recaptured Baltic 943 cod with more than 180 days at liberty, from the TET mark to the otolith edge, in relation to date 944 of incorporation. Left panel $=$ eastern Baltic cod, right panes $=$ western Baltic cod. Data shown are 945 relative element concentrations (Element:Ca ratios divided by the profile mean for each element) 946 with loess smoothed means and confidence interval bands. Minima $(\mathrm{Min})=$ blue symbols, maxima $947($ Max $)=$ red symbols. Vertical lines from extrema to $\mathrm{x}$-axis are shown to facilitate identification 948 the time of the year corresponding to the extrema. 
1 Table 1. Overview of samples used in this study. Values of length, age and days at liberty (DAL)

2 are given as mean \pm standard deviation with the range of values in brackets.

3

4 Collection Stock $\mathrm{n} \quad$ Length $(\mathrm{mm}) \quad$ Age (years) DAL (days)

5 TEST Kattegat $\quad 40 \quad 631 \pm 85(390-830) \quad 4.2 \pm 0.5(3-5)$ na

$6 \quad$ DECODE Eastern Baltic $53 \quad 242 \pm 64(150-350) \quad 3.2 \pm 0.6(2-4)$ na

$7 \quad T A B A C O D \quad$ Eastern Baltic $123 \quad 438 \pm 53(282-579)^{\dagger}$ na 368 $\pm 154(183-927)$

$8 T A B A C O D \quad$ Western Baltic $20 \quad 467 \pm 76(339-614)^{\dagger}$ na $316 \pm 13(186-748)$

9

10 Footnote: ${ }^{\dagger}$ Length at recapture

11 
1 Table 2. Regression statistics of minima in the chemical profiles (Min) in relation to winter zones 2 (WZ) in $D E C O D E$ otoliths, confidence intervals in brackets.

3

$\begin{array}{rllllll}4 & \text { Regulation } & \text { Element } & \text { Intercept } & \text { Slope } & \text { obs/groups } & \mathrm{r}^{2} \\ 5 & \text { Environment } & \mathrm{Ba} & 291(190-392) & 0.71(0.64-0.79) & 103 / 53 & 0.60 \\ 6 & & \mathrm{~Pb} & 104(9-198) & 0.82(0.75-0.82) & 114 / 53 & 0.73 \\ 7 & & \mathrm{Sr} & 206(87-325) & 0.85(0.76-0.93) & 99 / 51 & 0.57 \\ 8 & & & & & & \\ 9 & \text { Physiology } & \mathrm{Cu} & 150(63-237) & 0.79(0.72-0.86) & 105 / 52 & 0.67 \\ 10 & & \mathrm{P} & 110(26-193) & 0.84(0.77-0.91) & 103 / 53 & 0.81 \\ 11 & & \mathrm{Zn} & 166(79-253) & 0.81(0.74-0.89) & 110 / 53 & 0.73 \\ 12 & & & & & & \\ 13 & \text { Physiology and } & \mathrm{Mg} & 177(88-267) & 0.88(0.80-0.96) & 102 / 53 & 0.73 \\ 14 & \text { Environment } & \mathrm{Mn} & 305(183-428) & 0.76(0.65-0.86) & 90 / 51 & 0.62\end{array}$




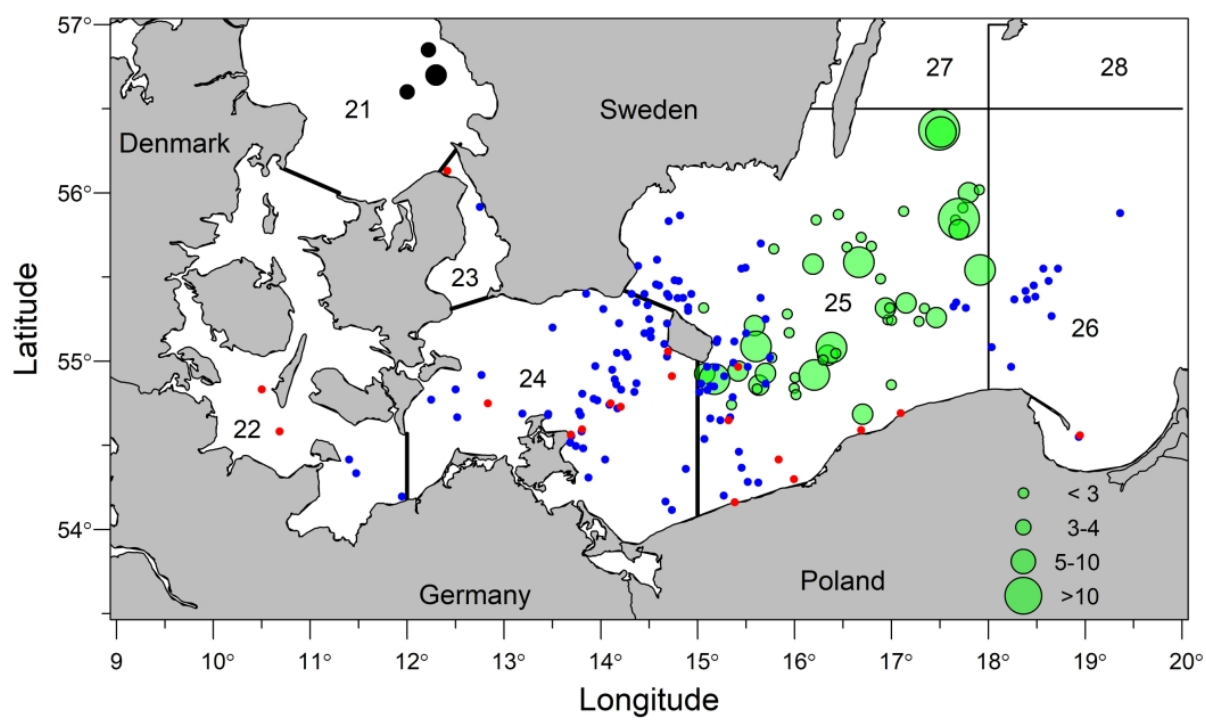

Map of the locations of cod from three different samples used in this study. Green symbols: Known-age samples of Baltic cod from the "ImproveD mEthodology for Baltic COD Age Estimation" (DECODE) project where age was obtained from patterns in daily otolith increment widths (varying size indicative of sample size). Blue and red symbols: Samples of recaptured Baltic cod from the international tagging project "Tagging Baltic Cod" (TABACOD), where symbols show the recapture locations of tagged cod (eastern Baltic cod = blue symbols; western Baltic cod = red symbols). Black symbols: Samples of cod from the Kattegat, which have a high contrast between otolith growth zones and therefore are used as test group to identify the best approach for the analyses of element profiles. Numbers identify ICES Subdivisions (SD), where SD 21: Kattegat, SD 22: Belt Sea, SD 23: Sound, SD 24: Arkona Sea, SD 25 Bornholm Sea, SD 26: Gdansk Bay and SD 28: Gotland Basin. The area consists of three management areas: Kattegat (SD 21), western Baltic Sea (SD 22 - 24) and eastern Baltic Sea (SD 25 - 32). Map created using the "maps" package ver. 3.3.0 of "R".

$241 \times 170 \mathrm{~mm}(300 \times 300 \mathrm{DPI})$ 


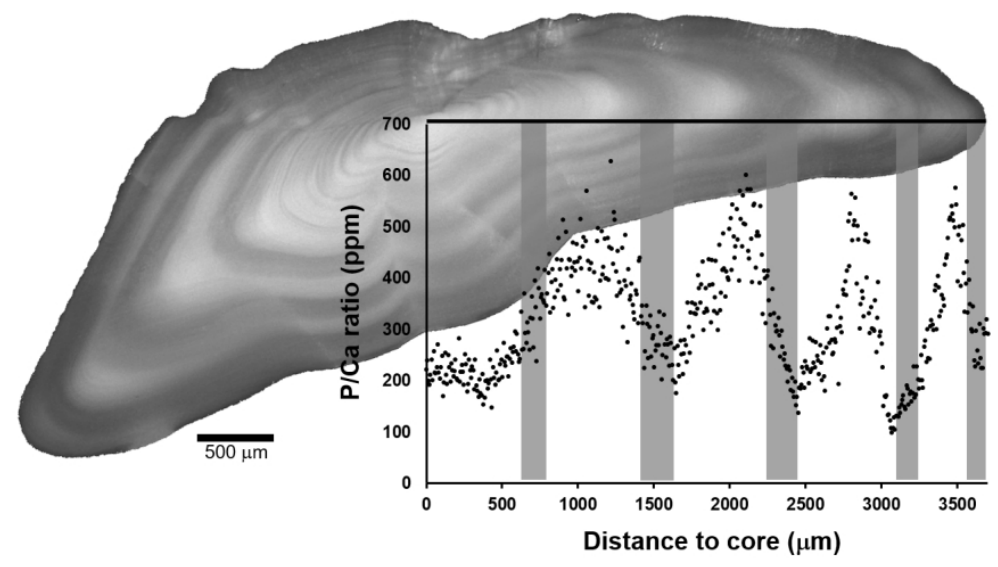

Transversal section of an otolith from a 4-year old cod caught in December 2010 in Kattegat from the test sample (TEST) characterized by high contrast between seasonal translucent and opaque zones with concurrent high age estimation precision and well established ageing protocols. TEST samples were used to identify the best setting for profile smoothing and peak detection. Otolith section is viewed under reflected light, with superimposed elemental profile of phosphorus (as P/Ca ratio) from the nucleus to the dorsal otolith edge and translucent seasonal growth zones indicated by grey vertical bars.

$290 \times 179 \mathrm{~mm}(150 \times 150 \mathrm{DPI})$ 

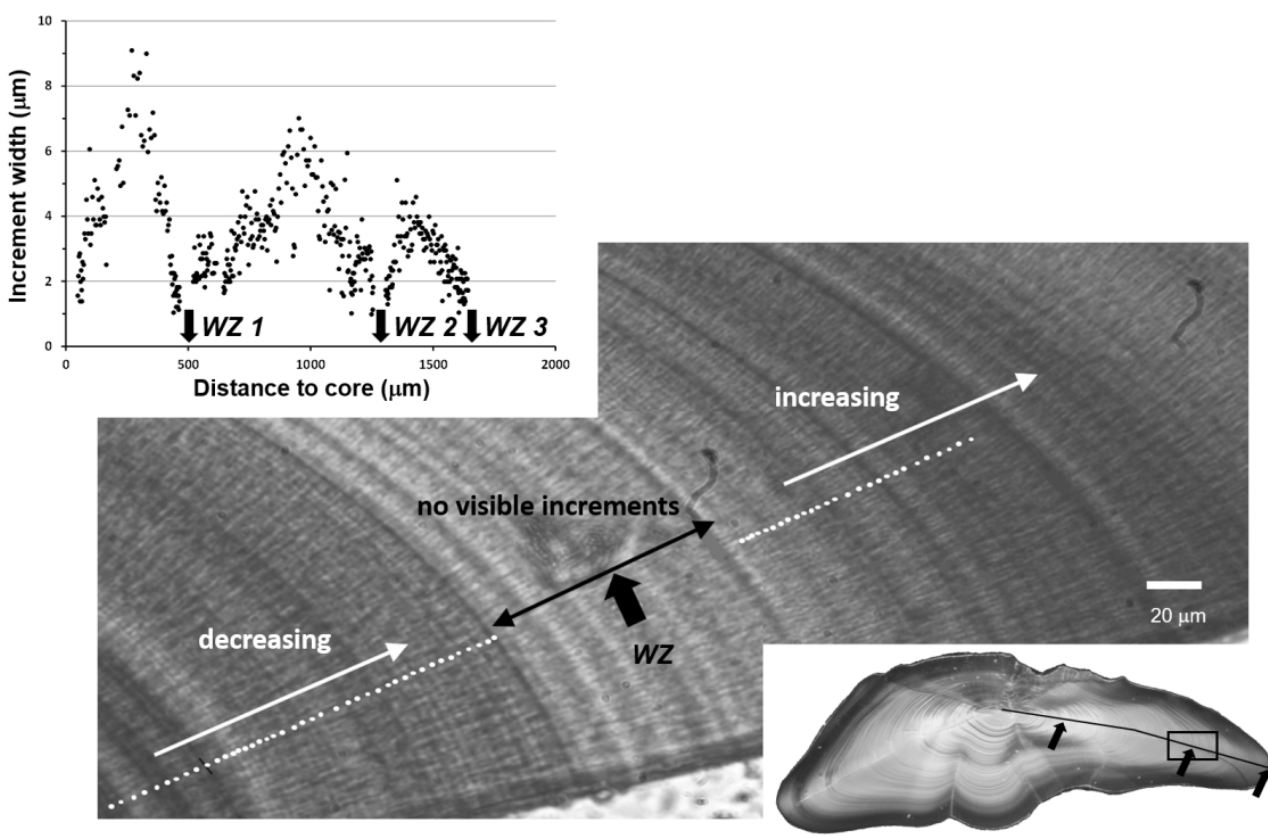

Transversal section of otolith of a 3-year old Baltic cod from the first validation collection, the DECODE samples, where age was obtained from patterns in daily otolith increment widths, viewed under reflected light (bottom right), where the black box indicates the otolith area viewed under 20x magnification and transmitted light (middle image). In this image, white dots indicate daily increments prior to and after a zone with no visible increments. The profile of daily increment widths from core to otolith edge (top left) shows how "winter zones" were identified. Winter zones (WZ) are indicated with arrows, where the distance of the midpoint of each zone to the core is the measurement used in the present analyses. Note that the last WZ has just started to form at the edge of the otolith and can therefore not be measured. Since the cod was caught in February and new growth zones are counted from the 1st January, this last zone corresponding to the edge, is counted when estimating the age of the fish. The arrows in the images of otolith cross section and magnified otolith zone showing daily increments correspond to the WZ identified in daily increment profile (top left).

$276 \times 180 \mathrm{~mm}(150 \times 150 \mathrm{DPI})$ 


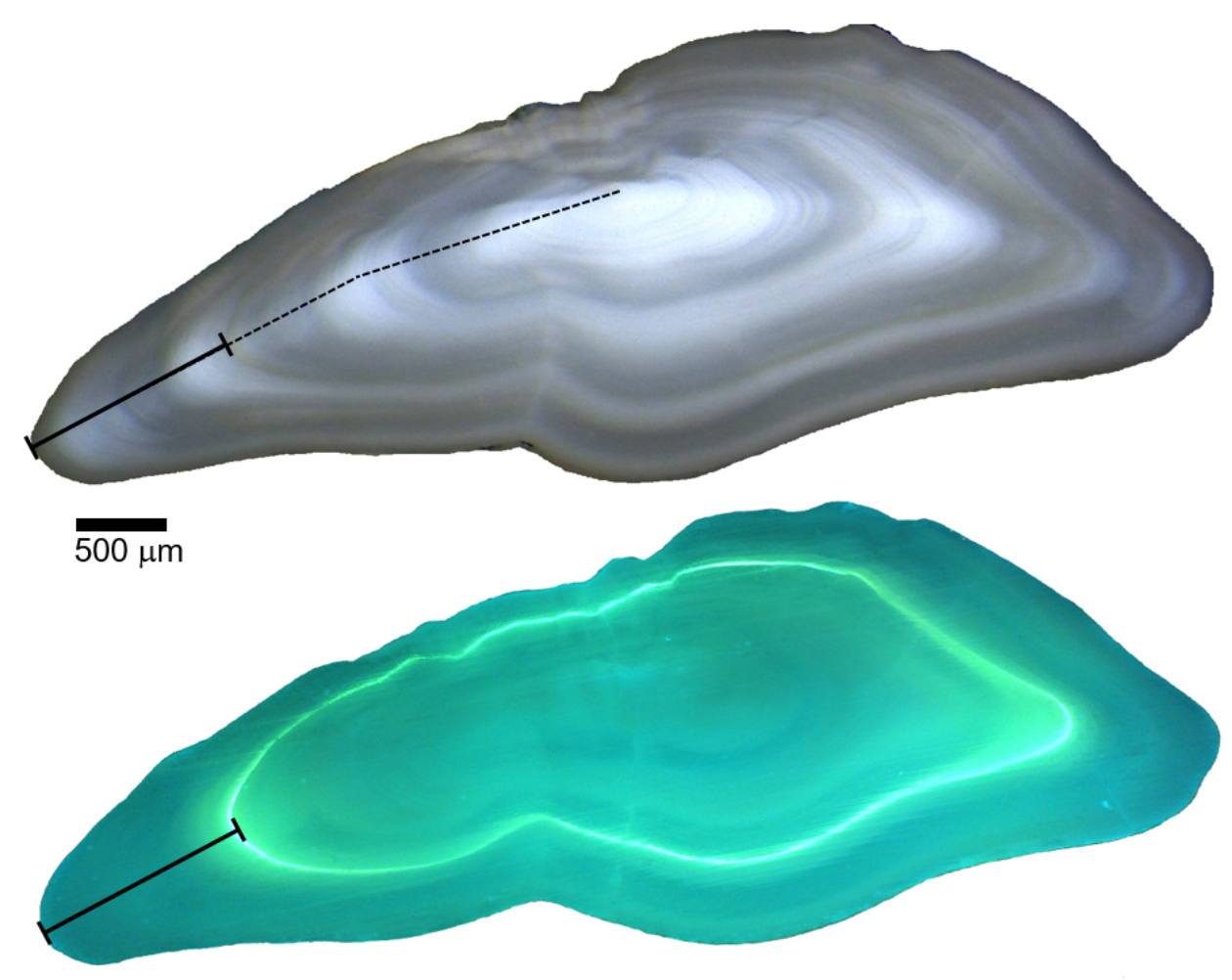

Transversal section of a tagged eastern Baltic cod otolith from the second validation sample, the TABACOD samples consisting of tagged and recaptured cod from the from the international tagging project "Tagging Baltic Cod", viewed under reflected light with the position of the laser transect indicated with a broken black line. The same otolith is shown under UV light showing the green fluorescent TET mark induced at release, where the part of the profile used in this study is indicated with a solid black line on both images. The cod was released at $54.60 \mathrm{~N}$ and $13.42 \mathrm{E}$ on the $03 / 11 / 2017$ at a length of $263 \mathrm{~mm}$ and recaptured at a length of $462 \mathrm{~mm}$ at $54.69 \mathrm{~N}$ and $13.19 \mathrm{E}$ on the 19/06/2019 after 593 days at liberty.

$$
164 \times 125 \mathrm{~mm}(150 \times 150 \text { DPI })
$$




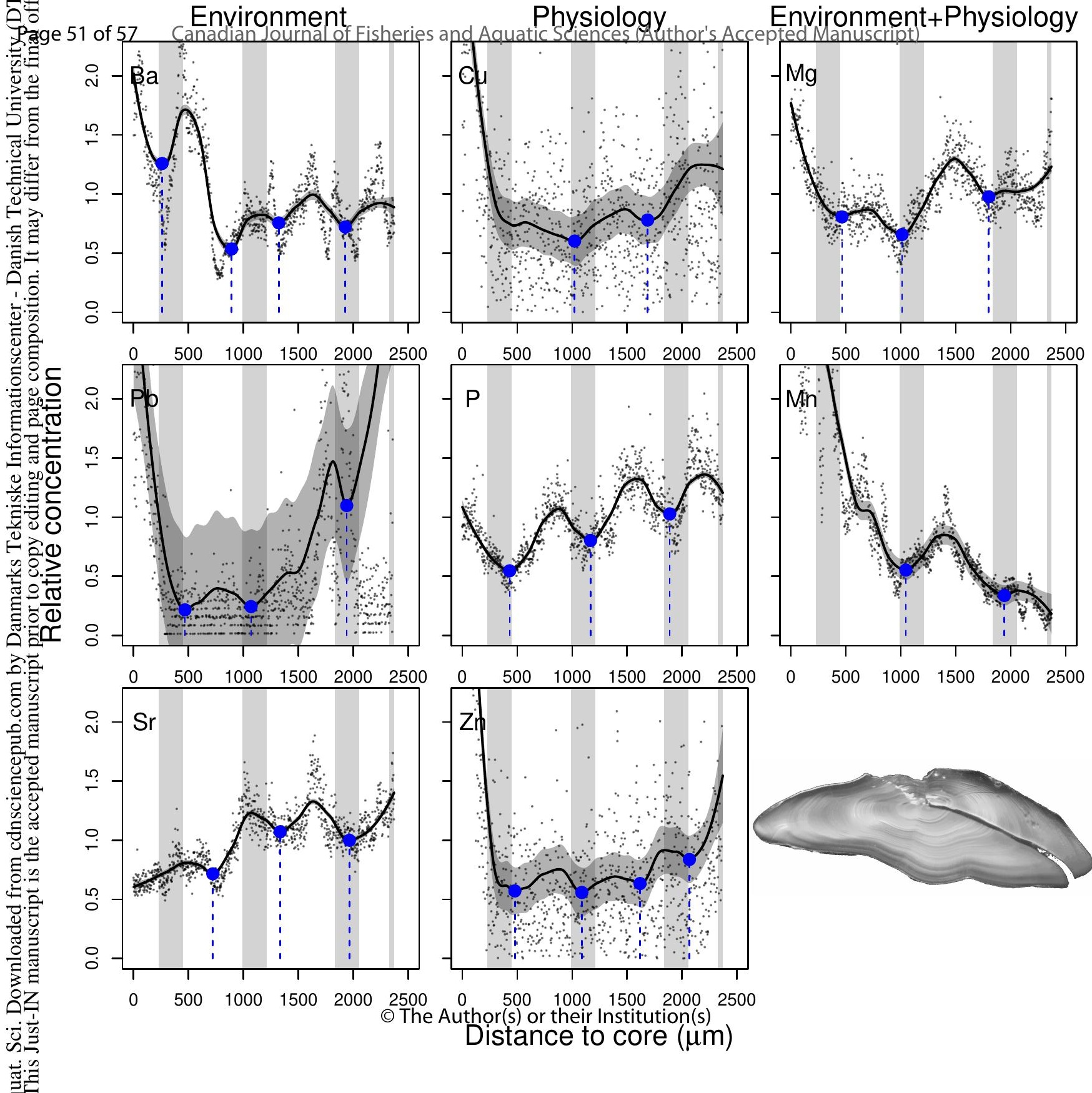




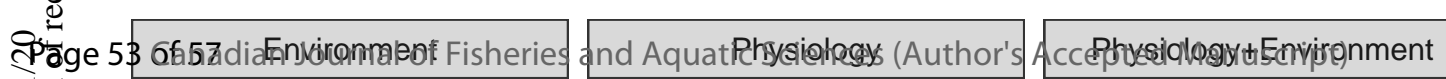
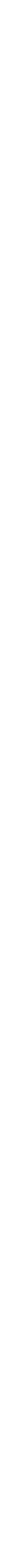

Known age - chemical minima 


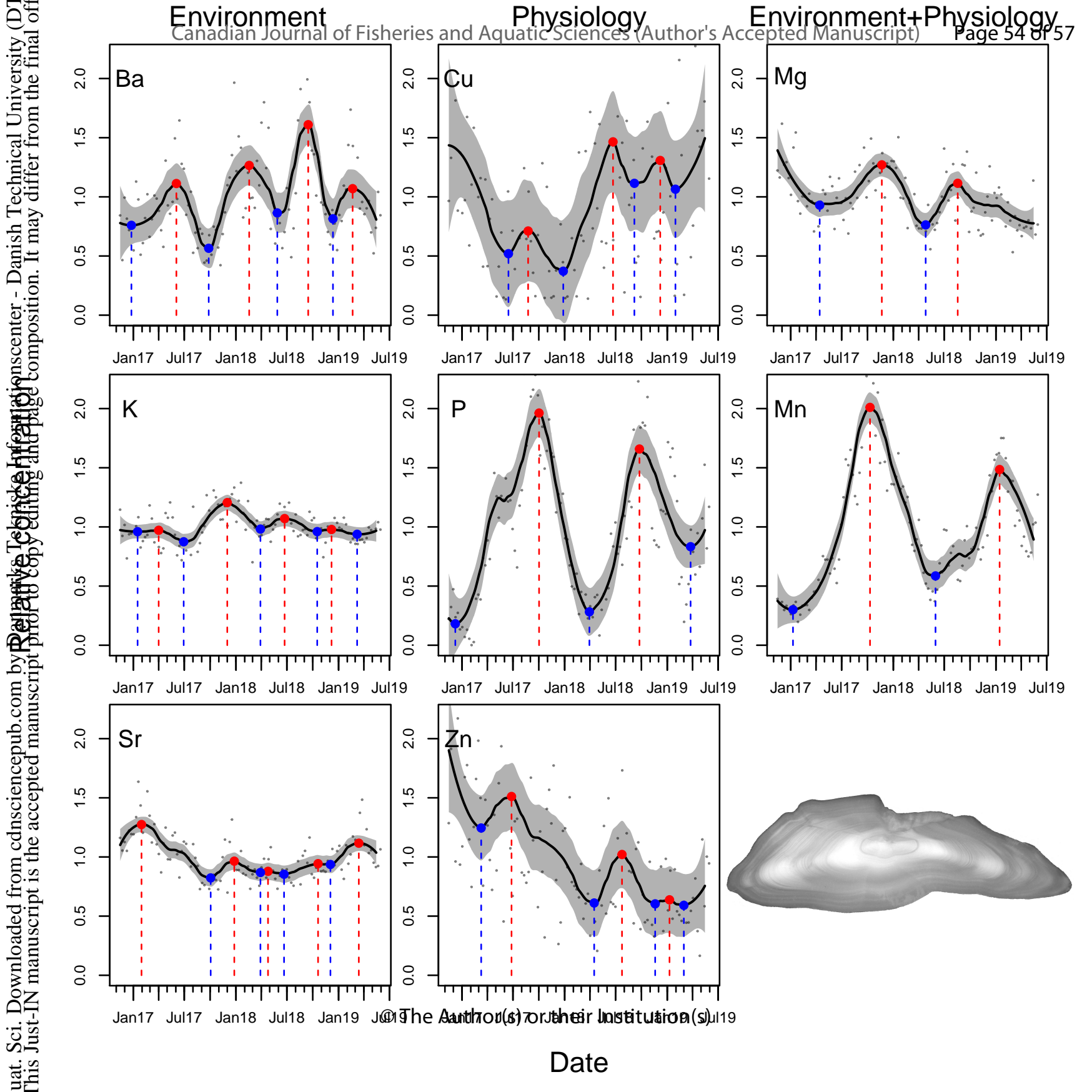




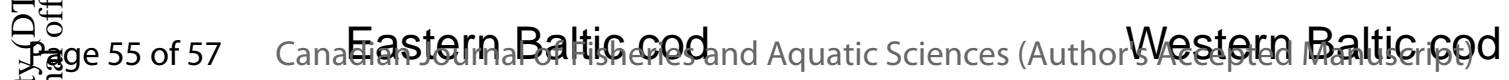
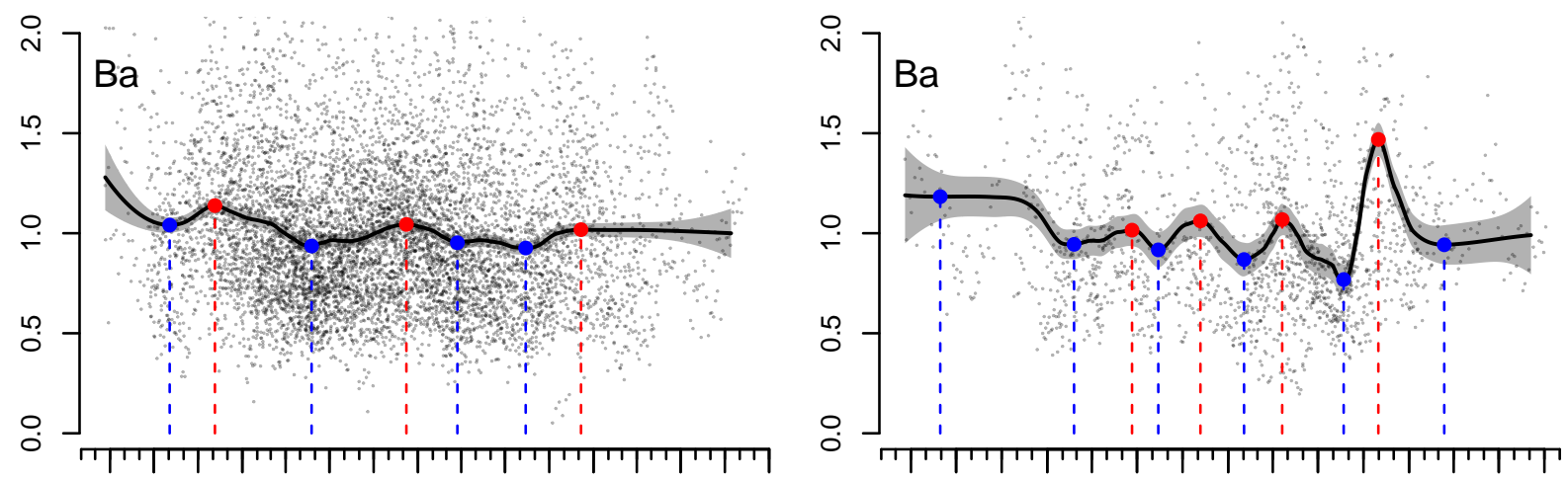

Jul16 Jan17 Jul17 Jan18 Jul18 Jan19 Jul19 Jan20

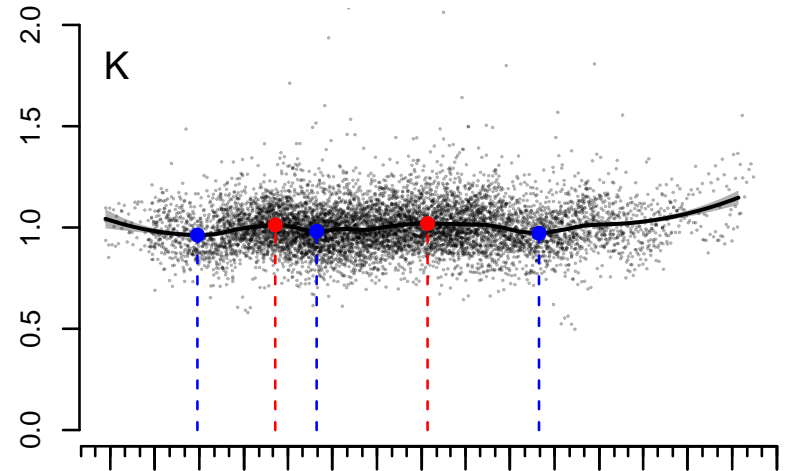

$\stackrel{\circ}{\text { N }}$

Jul16 Jan17 Jul17 Jan18 Jul18 Jan19 Jul19

인

Jul16 Jan17 Jul17 Jan18 Jul18 Jan19 Jul19 Jan20
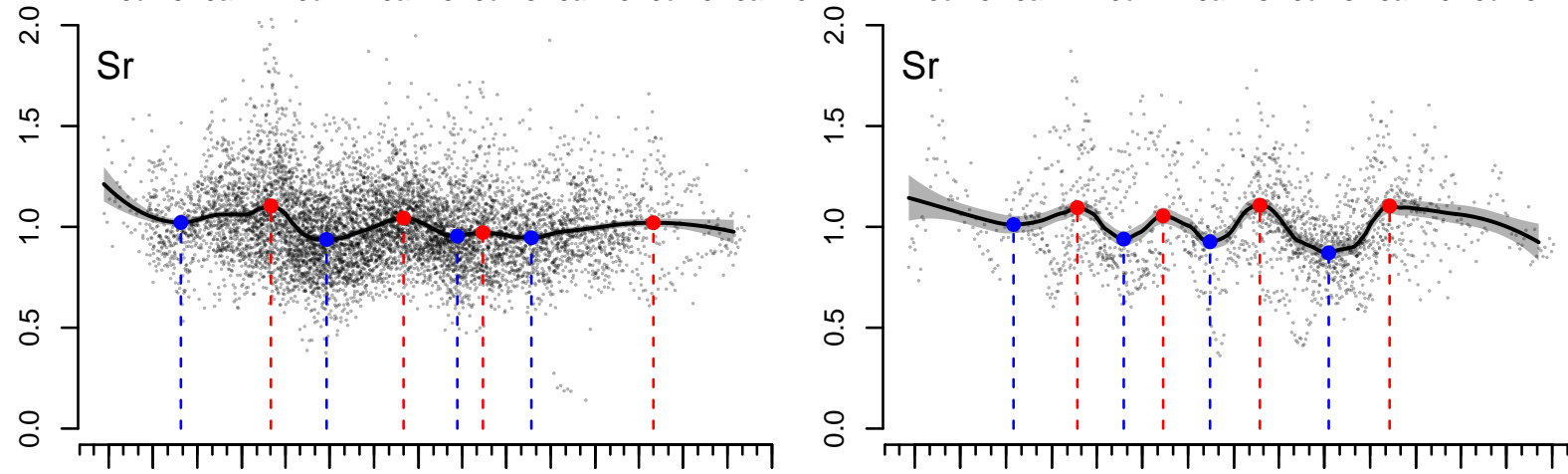

Jul16 Jan17 Jul17 Jan18 Juß98

Date 


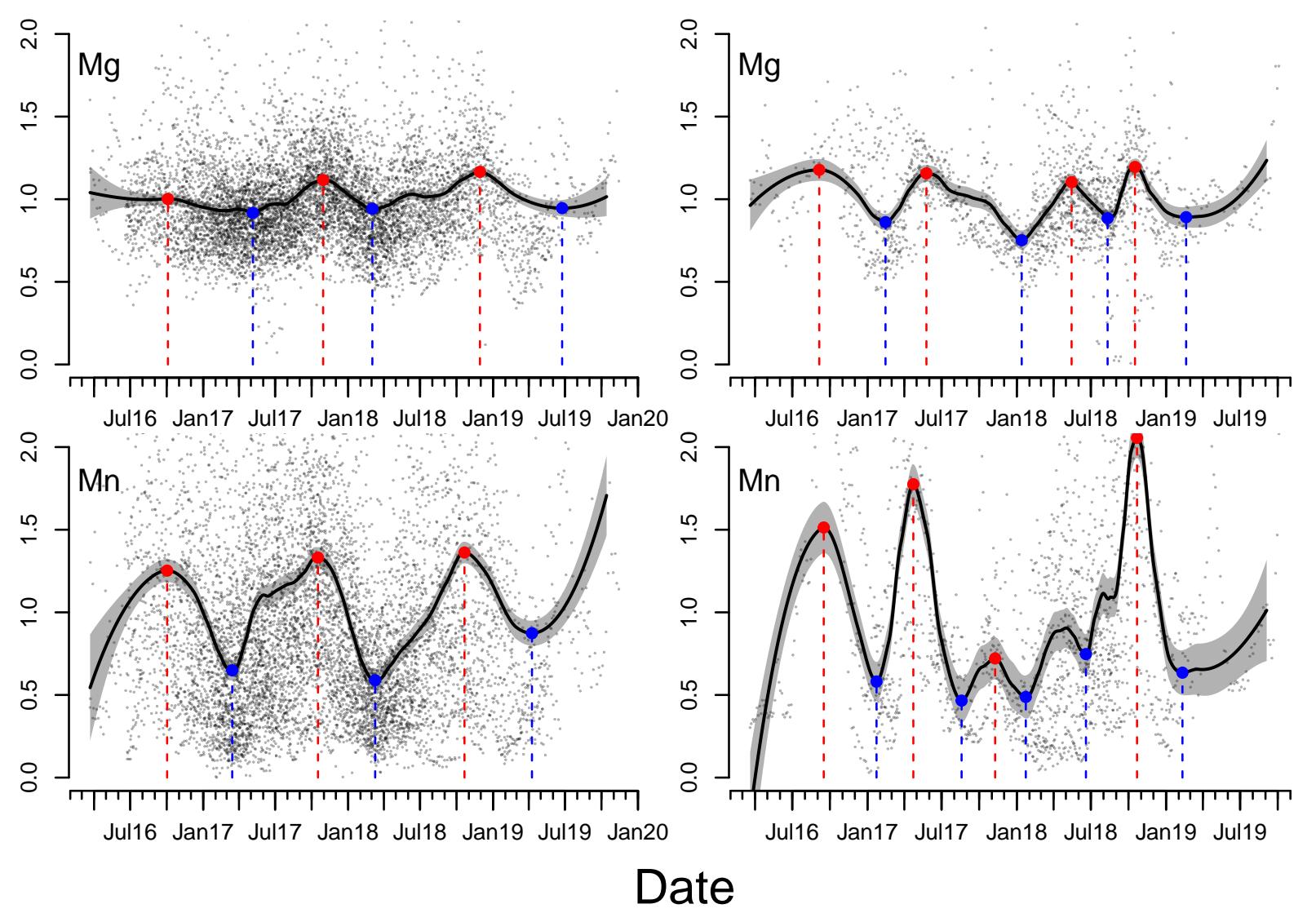

(๑) The Author(s) or their Institution(s) 


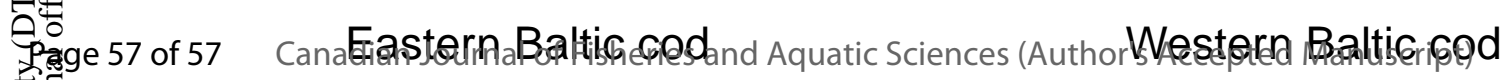
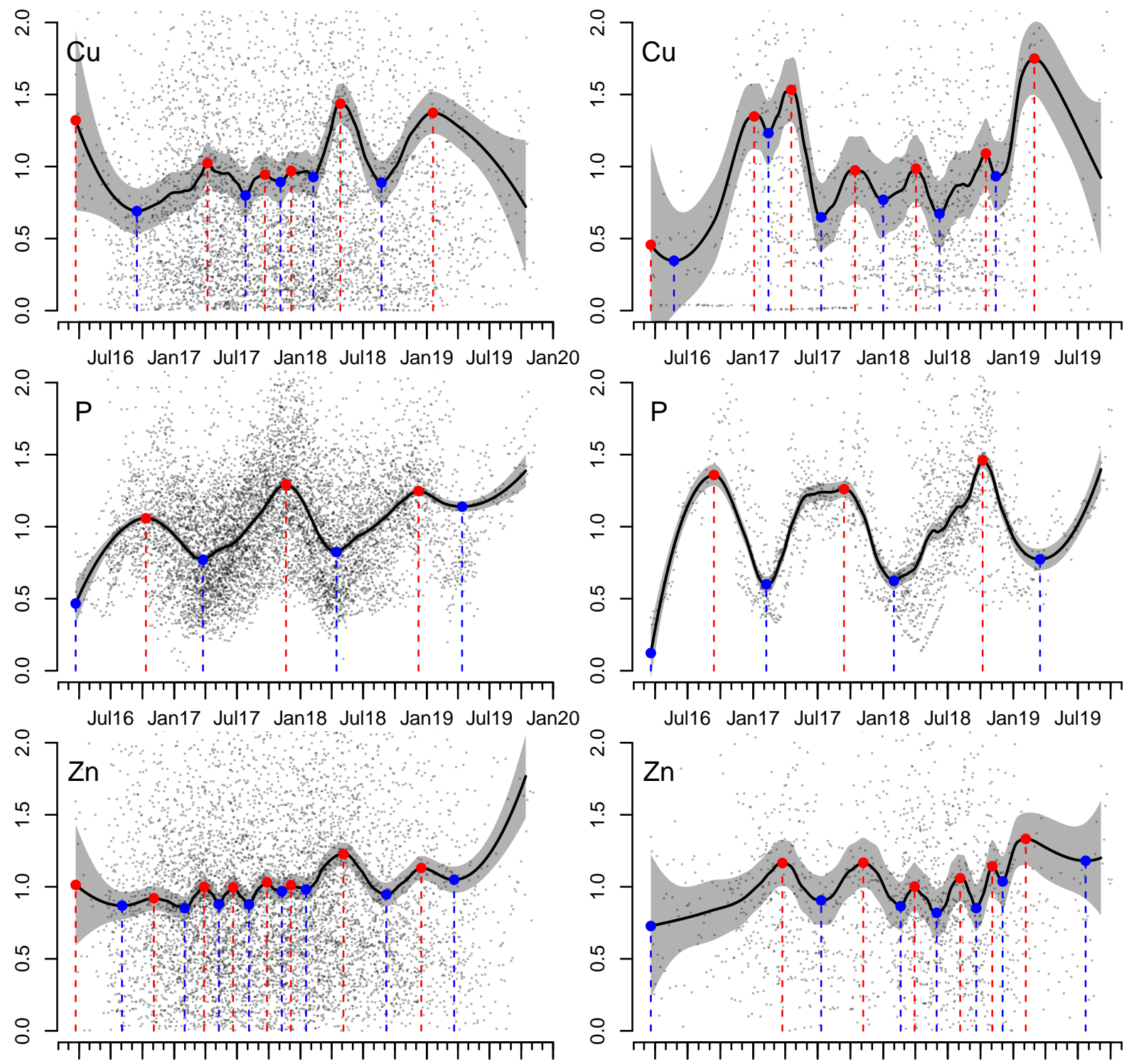

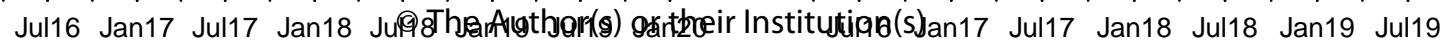

Date 